\title{
The Earliest-Generated Neurons of the Cat Cerebral Cortex: Characterization by MAP2 and Neurotransmitter Immunohistochemistry During Fetal Life
}

\author{
Jerold J. M. Chun ${ }^{\mathrm{a}}$ and Carla J. Shatz \\ Department of Neurobiology, Stanford University School of Medicine, Stanford, California 94305
}

The earliest-generated neurons of the cat cerebral cortex have been studied here during development using a combination of ${ }^{3} \mathrm{H}$-thymidine birthdating with immunohistochemistry for the neuron-specific protein MAP2 or for several neuropeptides/transmitters. These neurons are the first postmitotic cells of the cortex, with birthdates during the 1-week period preceding the genesis of cells of the adult cerebral cortex (Luskin and Shatz, 1985a; Chun et al., 1987). However, they are transient and the majority disappear by adulthood (Luskin and Shatz, 1985a; Chun and Shatz, 1989). When autoradiographic birthdating is combined with MAP2 immunostaining during fetal life, the entire population of these early-generated neurons appears to be stained, resulting in labeled bands above and below the cortical plate. The band above the cortical plate (in the marginal zone) contains earlygenerated neurons with horizontal morphologies, while the thicker band beneath the cortical plate (within the intermediate zone) contains the somata of early-generated neurons and their elaborate processes that are frequently directed towards the ventricular surface. In view of the correspondence between the location of the early-generated neurons and the MAP2-immunostained band beneath the cortical plate, we suggest that this combined approach can be used to define accurately the subdivision of the intermediate zone known as the subplate.

The early-generated neurons are also immunoreactive for GABA, neuropeptide Y (NPY), somatostatin (SRIF), and cholecystokinin (CCK) during fetal life. While GABA, NPY, and SRIF immunostaining could be detected by embryonic day 50 (E50), that for CCK was not found until E60. Moreover, there is a relationship between neuropeptide immunoreactivity and location within the cerebral wall. The marginal-zone neurons are immunoreactive only for CCK. The subplate neurons are immunoreactive for CCK, SRIF, and NPY. Most of those immunoreactive for SRIF tend to be clustered within the upper part of the subplate, while those immunoreactive for NPY tend to be located more deeply. Cells immunoreac-

\footnotetext{
Received June 8, 1988; revised Sept. 7, 1988; accepted Sept. 13, 1988.

We thank Drs. R. Vallee, W. Thcurkauf, and F. Luca for their gencrous gift of antibodies against MAP2; Dr. C. Evans for antibodies against NPY; M. Nakamura and M. Siegel for help during fetal surgeries; M. Nakamura for help with histology; and $\mathrm{C}$. Thomas for assistance with work processing. Supported by NIH Grant EY02858 (to C.J.S.) and NIH training grant GM07365 (to J.J.M.C.).

Correspondence should be addressed to Dr. Carla Shatz at the above address.

a Present address: Whitehead Institute for Biomedical Research, Nine Cambridge Center, Cambridge, MA 02142.

Copyright (C) 1989 Society for Neuroscience 0270-6474/89/051648-20\$02.00/0
}

tive for GABA are more uniformly distributed throughout the cerebral wall.

These observations demonstrate directly that the marginal zone and subplate contain peptide- and GABA-immunoreactive neurons that belong to the earliest-generated cell population of the cerebral cortex. The presence of these early-generated neurons, which achieve a remarkable degree of maturity during fetal life, suggests that they perform an essential, yet transient, role in the development of the cerebral cortex.

Two critical events that occur during the development of the mammalian neocortex are the establishment of the 6 cortical layers and the coordinate attainment of the proper sets of connections between the cortex and other parts of the brain. For these to occur, both migrating neurons (Rakic, 1972, 1977) and ingrowing axons that are destined for the cortical plate (developing neocortex) must traverse significant distances through an intervening region: the intermediate zone (or future white matter; Boulder Committee, 1970). The intermediate zone also contains "waiting" axon: many ingrowing axonal systems do not immediately invade the cortical plate but rather accumulate below it for several days to weeks (Lund and Mustari, 1977; Rakic, 1977; Wise et al., 1977; Wise and Jones, 1978; Innocenti, 1981; Shatz and Luskin, 1986).

The intermediate zone also contains a population of the earliest-generated cells of the telencephalon. In the cat, these cells have discrete birthdates: they are generated between embryonic days 24 (E24) and E30, while the neurons of the adult cortex are only generated thereafter (Luskin and Shatz, 1985a). Initially forming a layer of cells in the cerebral wall, the population is split apart by later-born neurons of the cortical plate. Thus, cells of this early-generated population come to be positioned not only beneath the cortical plate in a part of the intermediate zone known as the subplate, but also above the cortical plate in the marginal zone (future layer 1; Rickmann et al., 1977; Raedler and Raedler, 1978; Luskin and Shatz, 1985a). Both the marginal-zone and the subplate-cell populations are transient: although present in large numbers during fetal and early postnatal life, the majority vanish by 2-3 months after birth (Luskin and Shatz, 1985a; for a review, see Shatz et al., 1988).

Developmental studies relying on Nissl staining, Golgi impregnations, or electron microscopy have also identified neurons in the marginal and intermediate zones (Marginal zone: Cajal, 1891; Retzius, 1891; Astrom, 1967; Stensaas, 1967a-d; Sas and Sanides, 1970; Baron and Gallego, 1971; Marin-Padilla, 1971, 1972; Konig et al., 1975, 1981; Raedler and Sievers, 1976; 
Bradford et al., 1977; Raedler and Raedler, 1978; Edmunds and Parnavelas, 1982; Marin-Padilla and Marin-Padilla, 1982; Parnavelas and Edmunds, 1983; Intermediate zone: Kolliker, 1896; Cajal, 1911; Lorente de No, 1933; Godina, 1951; Astrom, 1967; Stensaas, 1967a-d; Marin-Padilla, 1971, 1972, 1978; Rickmann et al., 1977; Raedler and Raedler, 1978; Raedler et al., 1980; Rickmann and Wolff, 1981). Cells within the intermediate zone are also immunoreactive for neurotransmitters as reported for neuropeptide Y (NPY; Foster and Schultzberg, 1984; Woodhams et al., 1985), somatostatin (SRIF; Cavanagh and Parnavelas, 1988; Naus et al., 1988), GABA or its synthesizing enzyme glutamic acid decarboxylase (GABA or GAD; Wolff et al., 1984; Lauder et al., 1986), and postnatal cholecystokinin (CCK; Meyer and Wahle, 1988).

Here we examine whether the early-generated and transient marginal-zone and subplate neurons are those observed by Golgi impregnations, electron microscopy, or neurotransmitter immunoreactivity. Immunostaining for the neuron-specific protcin MAP2 (microtubule associated protein 2; Matus et al., 1981; Vallee, 1982; De Camilli et al., 1984; see Discussion), NPY, SRIF, CCK, or GABA was combined with ${ }^{3} \mathrm{H}$-thymidine autoradiographic birthdating to definitively prove the identity of subplate neurons studied using these different approaches. Moreover, these techniques have permitted us to examine the morphological appearance and quantitative distribution of the early-generated population within the developing fetal cat cerebral cortex. A brief report of some of these results has appeared previously (Chun et al., 1987).

\section{Materials and Methods}

Twenty-five cat brains between the ages of embryonic day (E) 46 and 65 (birth) plus one postnatal day (P) 7 and 1 adult brain analyzed for MAP2 were examined using immunohistochemistry with and without ${ }^{3} \mathrm{H}$-thymidine autoradiography. Table 1 summarizes the procedures used at each age. Fetal ages were determined by timed breedings as described previously (Luskin and Shatz, 1985a).

Surgical procedure. Surgical techniques and procedures have been described elsewhere (Luskin and Shatz, 1985a; Chun and Shatz, 1988a, b); an abbreviated version is included. Animals were first anesthetized with halothane $\left(1-2 \%\right.$ in $\left.\mathrm{O}_{2}\right)$ or intramuscular injection of ketamine $(20$ $\mathrm{mg} / \mathrm{kg})$ and acepromazine $(0.2 \mathrm{mg} / \mathrm{kg})$, followed by halothane $(0.5-2 \%$ in $\mathrm{O}_{2}$ ). Ventilation and heart rate were monitored continuously to ensure effective anesthesia. Animals also received an i.v. drip of 5\% dextrose/ saline. Postoperative care included analgesics and $24 \mathrm{hr} /$ day monitoring in our veterinary intensive care unit.

Fetal birthdate labeling was made through intrauterine injection of ${ }^{3} \mathrm{H}$-thymidine (NET 027Z, 76.1 Ci/mmol, DuPont, Wilmington, DE; $500-750 \mu \mathrm{Ci}$ /fetus) between the ages of E26 and E28 in order to specifically label the early-generated population of subplate and marginalzone neurons (Luskin and Shatz, 1985a; Chun et al., 1987).

Tissue preparation for histology. Fetuses were anesthetized by transplacental halothane, and postnatal animals were anesthetized using a combination of ketamine $(20 \mathrm{mg} / \mathrm{kg}$ plus acepromazine $0.2 \mathrm{mg} / \mathrm{kg})$ and nembutal $(50 \mathrm{mg} / \mathrm{kg})$. Anesthetized animals were then perfused using a peristaltic pump at flow rates ranging from $3.5-10 \mathrm{ml} / \mathrm{min}$ for the youngest to oldest ages (E65). Following an initial wash with Ringer's solution ( $124 \mathrm{~mm} \mathrm{NaCl}, 5 \mathrm{~mm} \mathrm{KCl}, 1.15 \mathrm{mM} \mathrm{KH}_{2} \mathrm{PO}_{4}, 1.15 \mathrm{~mm} \mathrm{MgSO}_{4}\left(7 \mathrm{H}_{2} \mathrm{O}\right)$, $2.5 \mathrm{~mm} \mathrm{CaCl}_{2}, 25 \mathrm{~mm} \mathrm{NaHCO}_{3}, 10 \mathrm{mM}$ glucose; $\mathrm{pH} \mathrm{7.4)} \mathrm{at} 25^{\circ} \mathrm{C}$ for 5 min, animals were perfused with fresh $4 \%$ paraformaldehyde in $0.1 \mathrm{M}$ monobasic sodium phosphate buffer, $\mathrm{pH} 7.4$ (fixative), for $30 \mathrm{~min}$ at $25^{\circ} \mathrm{C}$. Brains were removed and placed into circulating, fresh fixative for $12-18 \mathrm{hr}$ at $4^{\circ} \mathrm{C}$. Brains sectioned by cryostat were transferred from fixative into circulating buffer containing PBS $(20 \mathrm{~mm}$ monobasic sodium phosphate, $150 \mathrm{~mm} \mathrm{NaCl}, \mathrm{pH} 7.4$ ) with $6 \%$ sucrose and $0.025 \%$ $\mathrm{NaN}_{3}$ for $18-24 \mathrm{hr}$ at $4^{\circ} \mathrm{C}$. Rapid tissue freezing was accomplished by immersion into dry ice-cooled liquid $\mathrm{CCl}_{2} \mathrm{~F}_{2}$. Brains were either sectioned immediately at $8-10 \mu \mathrm{m}$ or stored at $-60^{\circ} \mathrm{C}$ and processed within $48 \mathrm{hr}$. Sections through the telencephalon were cut in the coronal plane
Table 1. Experimental age and analysis performed

\begin{tabular}{|c|c|c|c|c|c|}
\hline Age & $\begin{array}{l}\text { No. of } \\
\text { animals }\end{array}$ & $\begin{array}{l}{ }^{3} \mathrm{H}- \\
\text { thymidine }\end{array}$ & MAP2 & GABA & $\begin{array}{l}\text { Pep- } \\
\text { tides }\end{array}$ \\
\hline E46 & 1 & + & + & & \\
\hline E48 blot & 1 & & & & \\
\hline E50 & 2 & + & + & + & + \\
\hline E50 & 2 & & + & + & + \\
\hline E52 & 2 & & + & & \\
\hline E54 & 1 & + & + & + & + \\
\hline E56 blot & 1 & & & & \\
\hline E56 & 3 & + & + & + & + \\
\hline E56 & 1 & & + & + & + \\
\hline E58 & 2 & + & + & + & + \\
\hline E58 & 3 & & + & + & + \\
\hline E60 & 2 & & + & + & + \\
\hline E65 & 2 & & + & + & + \\
\hline P7 & 1 & + & + & + & + \\
\hline Adult blot & 1 & & & & \\
\hline
\end{tabular}

with an emphasis on neocortex at the level of the lateral geniculate nucleus. Mounted sections were stored at $-20^{\circ} \mathrm{C}$ and processed for immunohistochemistry within $4 \mathrm{hr}$.

Brains sectioned by Vibratome were fixed identically, then transferred into buffer without sucrose. After $18-24 \mathrm{hr}$, brains were embedded in $30 \%$ albumin plus $0.5 \%$ gelatin cross-linked with $5 \%(\mathrm{v} / \mathrm{v})$ of $50 \% \mathrm{glu}$ taraldehyde and cut at $80 \mu \mathrm{m}$ (fetal material) in the coronal plane. Sections were stored in PBS plus $0.025 \%$ sodium azide at $4^{\circ} \mathrm{C}$ and then processed for immunohistochemistry. (For further details, see Chun and Shatz, 1988a, b.)

Immunohistochemistry and autoradiography. Immunohistochemical reagents employed in this study are summarized in Table 2 . Sections were first preincubated for $1 \mathrm{hr}$ at $25^{\circ} \mathrm{C}$ in "incubation buffer" containing PBS, $0.02 \%$ sodium azide $\left(\mathrm{NaN}_{3}\right), 2.5 \% \mathrm{BSA}$ (Sigma, fraction $\mathrm{V}$ ), and $0.3 \%$ Triton X-100 (Sigma), filtered with a $0.22 \mu \mathrm{m}$ Millex-GV membrane (Millipore, Bedford, MA) just prior to use. The incubation buffer was then drained away, and fresh buffer was applied to the sections with the addition of the primary antiserum/antibody. Blocking controls were carried out identically except for the addition of the appropriate blocking reagent to the buffer containing the primary antibody. After incubation for 15-24 hr, sections were washed (in PBS without $\mathrm{NaN}_{3}, 4$ changes over $30 \mathrm{~min}$ ), and bound antibody was localized using an avidin-biotincomplex system ( $\mathrm{ABC}$; Vector Labs, Burlingame, $\mathrm{CA}$ ) as follows: the sections were incubated with biotinylated secondary antibody $(60 \mathrm{~min})$, washed in PBS (4 changes over 30 min), incubated in ABC (horseradish peroxidase or HRP) solution (40-60 min), and then washed in $50 \mathrm{~mm}$ Tris-buffered saline (TBS; $50 \mathrm{~mm}$ Tris-HCl, $150 \mathrm{~mm} \mathrm{NaCl}$, pH 7.5; 4 changes over $30 \mathrm{~min}$ ). The HRP reaction commenced with the addition

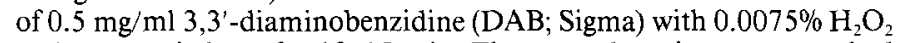
and was carried out for $10-15 \mathrm{~min}$. The reacted sections were washed in TBS ( 20 min with 2 changes), followed by 3 washes in distilled water, dehydration in graded ethanols, and immersion in $100 \%$ xylene for 8 hr. Sections were then either coverslipped in Permount (Fisher Scientific, Fair Lawn, NJ) and observed or rehydrated and dipped in $0.4 \%$ osmium tetroxide in distilled water for $30 \mathrm{sec}$ to enhance the HRP reaction product. Sections were dehydrated, coverslipped, and observed. Those destined for ${ }^{3} \mathrm{H}$-thymidine autoradiography were osmicated as above, then washed in distilled water, dried, dipped in emulsion, exposed, and developed as described previously (Luskin and Shatz, 1985a). Cells with greater than $20 \%$ of the maximum number of silvergrains over their nuclei were considered labeled.

Figure 1 illustrates representative immunostained sections and some of their appropriate controls for MAP2 (Fig. 1, $A-C$ ), GABA (Fig. 1, $D, E$ ), and NPY (Fig. $1, F, G$ ). Specific immunostaining was not produced by normal rabbit serum (polyclonal antibodies) or isotype-matched controls (for MAP2). Further, all neuropeptide or GABA immunoreactivity was blocked by the simultaneous incubation of antisera with the appropriate neuropeptide or GABA, respectively, and only the respective reagent was capable of blocking immunostaining. 
Figure 1. Examples of immunostained sections from the fetal neocortex and adjacent control sections are shown for MAP2 $(A-C)$, GABA $(D, E)$, and NPY $(F, G)$. Since both a mouse monoclonal antibody and rabbit polyclonal antiserum were used against MAP2 (both giving qualitatively identical reslts), the MAP2-immunostained section $(A)$ is compared to the mouse isotype-matched $(B)$ and the normal rabbit serum controls $(C)$. Similarly, the GABA-immunostained section $(D$; Materials and Methods for explanation of vertical line) contrasts with the blocking control in which $80 \mu \mathrm{M}$ GABA was present during the primary antibody incubation. All neuropeptides could be blocked by their respective control peptides (not shown) and, in addition, NPY $(F)$ could be blocked by a $15 \mathrm{~nm}$ solution of the true TRQRY amide $(G)$ but not by related peptides (see Table 2). $A-E$ are from an E50 neocortex; $F$ and $G$ from an E54 neocortex. Pial surface is towards the top of each section. The $300 \mu \mathrm{m}$ scale bar in $A$ pertains to $A-E ; 30 \mu \mathrm{m}$ bar in $F$ refers to $F$ and $G$.

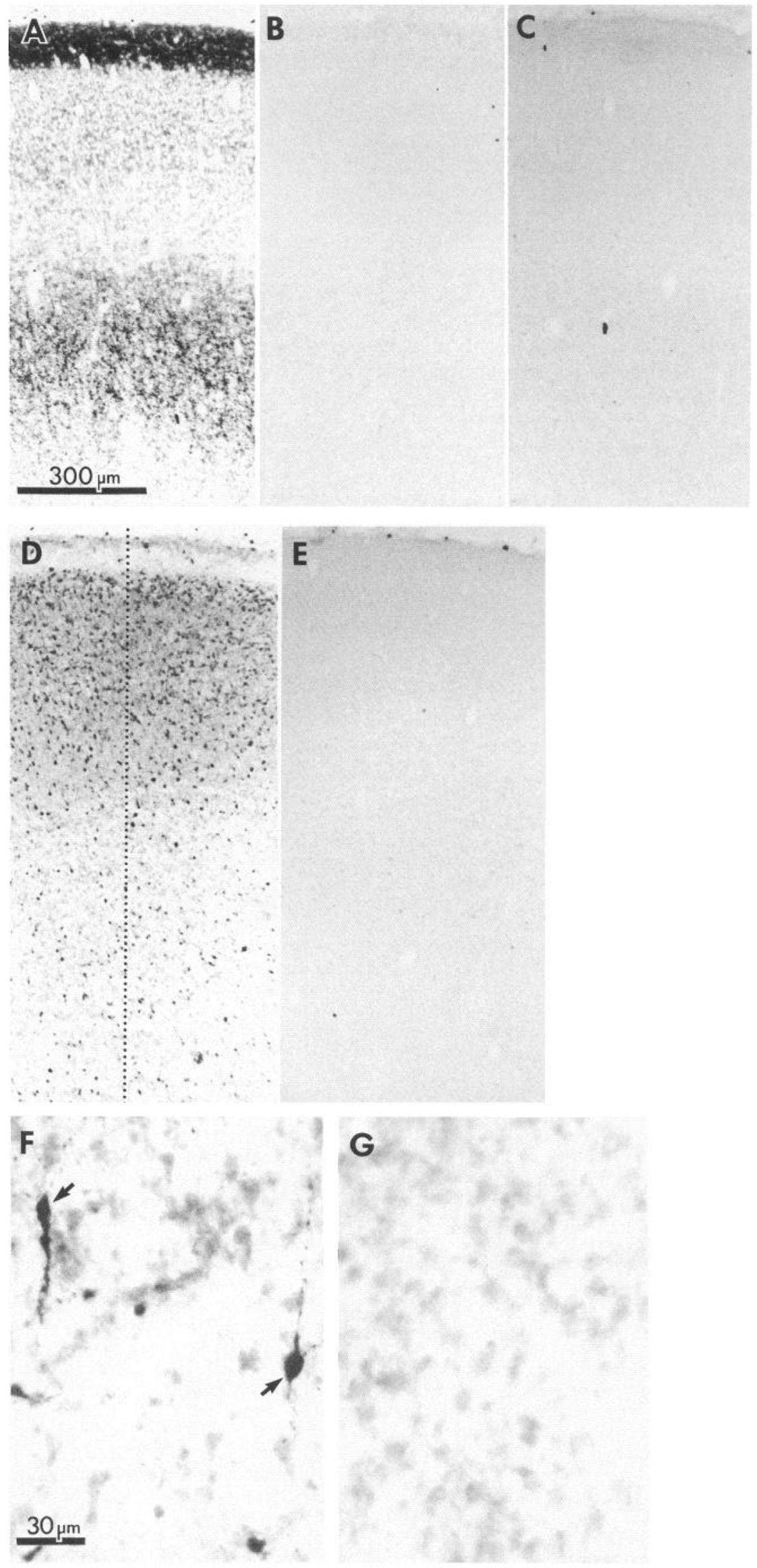




\begin{tabular}{|c|c|c|}
\hline Reagent & Dilution & Source \\
\hline NPY & $1: 1000$ & $\begin{array}{l}\text { Dr. C. Evans, Stanford } \\
\text { University }\end{array}$ \\
\hline SRIF & $1: 1000$ & $\begin{array}{l}\text { Immuno Nuclear } \\
\text { Corporation, Stillwater, } \\
\mathrm{MN}\end{array}$ \\
\hline CCK & $1: 1000$ & $\begin{array}{l}\text { Immuno Nuclear } \\
\text { Corporation }\end{array}$ \\
\hline GABA & $1: 2000$ & $\begin{array}{l}\text { Immuno Nuclear } \\
\text { Corporation }\end{array}$ \\
\hline MAP2 & $1: 2500$ & $\begin{array}{l}\text { Drs. W. Theurkauf and R. } \\
\text { Vallee; Worcester } \\
\text { Foundation, Shrewsbury, } \\
\text { MA }\end{array}$ \\
\hline $\begin{array}{l}\text { Mouse-anti-MAP2 } \\
\text { monoclonal (MAP2-3) }\end{array}$ & $1: 30$ & Drs. F. Luca and R. Vallee \\
\hline $\begin{array}{l}\text { Mouse IgG1 and IgG2b } \\
\text { controls }\end{array}$ & $1: 30$ & $\begin{array}{l}\text { Dr. I. Weismann, Stanford } \\
\text { University }\end{array}$ \\
\hline Normal rabbit sera & $1: 1000$ & Various sources \\
\hline NPY, CCK, SRIF peptides & $50 \mathrm{~nm}$ & $\begin{array}{l}\text { Peninsula Labs, Belmont, } \\
\text { CA }\end{array}$ \\
\hline $\begin{array}{l}\text { TRQRYamide, } \\
\text { YPMRFamide, } \\
\text { YRPRYamide }\end{array}$ & $15 \mathrm{~nm}$ & Dr. C. Evans \\
\hline GABA & $80 \mu \mathrm{M}$ & $\begin{array}{l}\text { Sigma Chemical Company, } \\
\text { St. Louis, MO }\end{array}$ \\
\hline
\end{tabular}

Western blot analyses for MAP2. Animals prepared for Western blot analyses first were perfused with Ringer's solution to remove blood components. The brains were then rapidly removed from the cranium and processed using a procedure modified from Berkowitz et al. (1977). Twenty $\mathrm{ml}$ of brain tissue (including all of the telencephalon) were homogenized in $60 \mathrm{ml}$ of buffer $(0.1 \mathrm{M}$ Pipes-NaOH, 2 mM EGTA, 1 mM $\mathrm{MgSO}_{4}, 4 \mathrm{M}$ glycerol, $\mathrm{pH} 6.9$ at $4^{\circ} \mathrm{C}$ ) with a motor-driven teflonglass homogenizer. The homogenate was centrifuged for $15 \mathrm{~min}$ at 10,200 $g$ using a Beckman JS13 rotor. The pellet was discarded and the supernatant recentrifuged for $70 \mathrm{~min}$ at 142,800 $\mathrm{g}$ using a Beckman Ti50 rotor. The resulting new supernatant was combined with $5 \times$ boiling sample buffer $(5 \times$ buffer contains $10 \%$ SDS, 5 mM DTT, $50 \%$ glycerol, $50 \mathrm{~mm}$ Tris- $\mathrm{HCl}, \mathrm{pH} 8$, plus bromophenyl blue) to yield a $1 \times$ solution. Solubilized samples were stored at $-80^{\circ} \mathrm{C}$ or immediately electrophoresed on a $4-15 \%$ gradient polyacrylamide gel using SDS-PAGE (Laemmli, 1970) along with molecular weight standards (Sigma, St. Louis, MO). After electrophoresis, the gel lanes were either cut out and stained with Coomassie blue or transferred electrophoretically onto nitrocellulose membrane (Towbin et al., 1979; Bittner et al., 1980). Following transfer, the nitrocellulose was incubated at room temperature with gentle agitation in $5 \% \mathrm{BSA}$ and $10 \mathrm{~mm}$ TBS plus $0.1 \%$ Triton $\mathrm{X}-100$ and $0.02 \% \mathrm{NaN}_{3}$ for $8-12 \mathrm{hr}$, followed by addition of the primary antiserum or normal rabbit serum controls $(1: 20,000)$ for $12-24 \mathrm{hr}$. The bound antibody was visualized using the following schedule: the membrane was removed from the primary antiserum and washed with 5 changes of $10 \mathrm{~mm}$ TBS over a 50 -min period. Using a Vectastain ABC kit (Vector Labs, Burlingame, CA), the membrane was exposed to the secondary antibody diluted in $10 \mathrm{~mm}$ TBS for $2 \mathrm{hr}$, washed as above, then similarly exposed to the $\mathrm{ABC}$ reagent for $1 \mathrm{hr}$ and again washed. The HRP reaction was carried out using a solution of $17 \%$ methanol, $0.5 \%$ 4-chloro-1-napthol and $0.15 \% \mathrm{H}_{2} \mathrm{O}_{2}$ diluted into $10 \mathrm{mM}$ TBS and reacted for $1 \mathrm{~min}$ at room temperature. The membrane was then washed in distilled water, dried, and stored in the dark. The presence of MAP2 in both the adult and the prenatal cat is shown in the Western blots of Figure 2.

Measurements. The areas of the subplate, the cortical plate, or the marginal zone were determined by making camera lucida drawings of at least 4 MAP2-immunostained sections in the following manner. First,

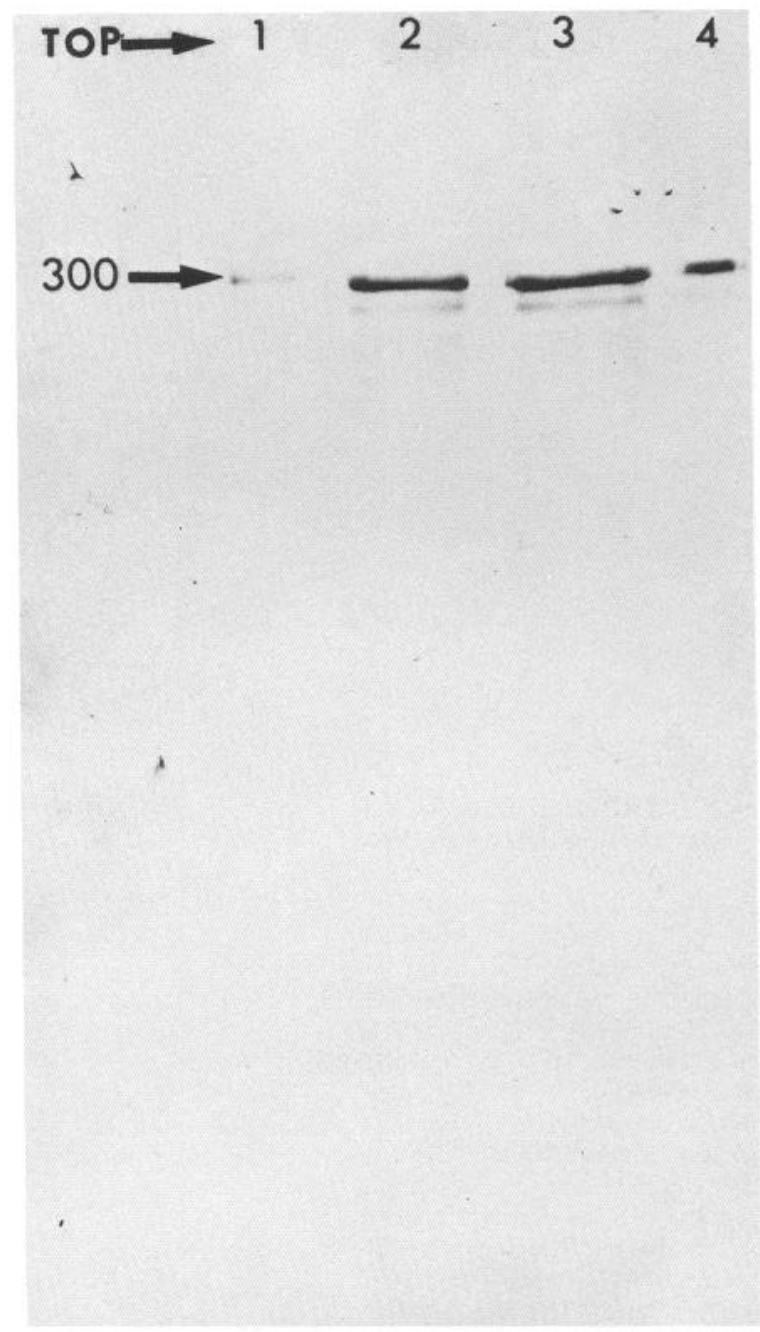

Figure 2. Adult-like MAP2 is present in fetal brain by antigen transfer analyses (Western blots). Reducing conditions were used in non-quantitative transfers of SDS-PAGE (4-15\% gradient gel) to reveal the characteristic $300 \mathrm{MW}$ doublet of MAP2 in adult (lanes 1-3) and at E48 (lane 4). No other major bands were observed. These bands were absent from control blots.

the base of the subplate (farthest from the pial surface) was determined. A conservative value was obtained by designating the base of the subplate as that region where MAP2-immunoreactive processes become very sparse (see Fig. 6). The top border of the subplate (i.e., just below the cortical plate) was established either by using ${ }^{3} \mathrm{H}$-thymidine labeling to mark the location of the most superficial of the early-generated subplate cells (Luskin and Shatz, 1985a; see Fig. 7) or in conjunction with MAP2 immunohistochemistry (Chun et al., 1987; see Fig. 6). The area of the subplate extending from beneath the cingulate gyrus to beneath the ectosylvian gyrus was measured. Area measurements of the cortical plate or marginal zone were made in a similar fashion so that the length of cortex included in the measurements was equal to that determined for the subplate. The resulting areas were then digitized and calculated using a Sigma-Scan measurement system (Jandel Scientific, Sausalito, CA).

Counts of cells immunostained by MAP2, NPY, SRIF, or CCK at ages E50, E56, and E60 were made in similar regions at each age within the medial bank of the lateral gyrus and within the ectosylvian gyrus (1 animal at each age was analyzed). To accomplish this, a line was drawn from the pial surface to the ventricular surface as in Figure $1 D$. The number of immunostained cells was counted $($ at $\times 312)$ within a window $20 \mu \mathrm{m}$ deep and $400 \mu \mathrm{m}$ wide moved in adjacent steps from the pial surface to the ventricular surface along the line. Both regions of cortex were counted in this fashion in each of 5 sections. The data were com- 
Figure 3. MAP2-immunoreactive layer is present within the intermediate zone throughout the fetal telencephalon. An $80-\mu \mathrm{m}$-thick coronal Vibratome section cut in the coronal plane was immunostained for MAP2 at E52. One-half of the brain is shown. A dark MAP2-immunoreactive layer can be seen below and parallel to the less immunostained cortical plate $(C P)$. The marginal zone $(M Z)$ is also stained. The heavily stained layer extends well into the intermediate zone (IZ). Overlying the ventricle $(V)$ is the ventricular zone $(V Z)$, which also exhibits faint MAP2immunoreactivity. Non-neocortical structures such as the hippocampal formation $(H)$ and the lateral geniculate nucleus $(L)$ are also labeled by MAP2 immunostaining. The region within the rectangle is enlarged in Figure 6. $D$, dorsal; $M$, medial.

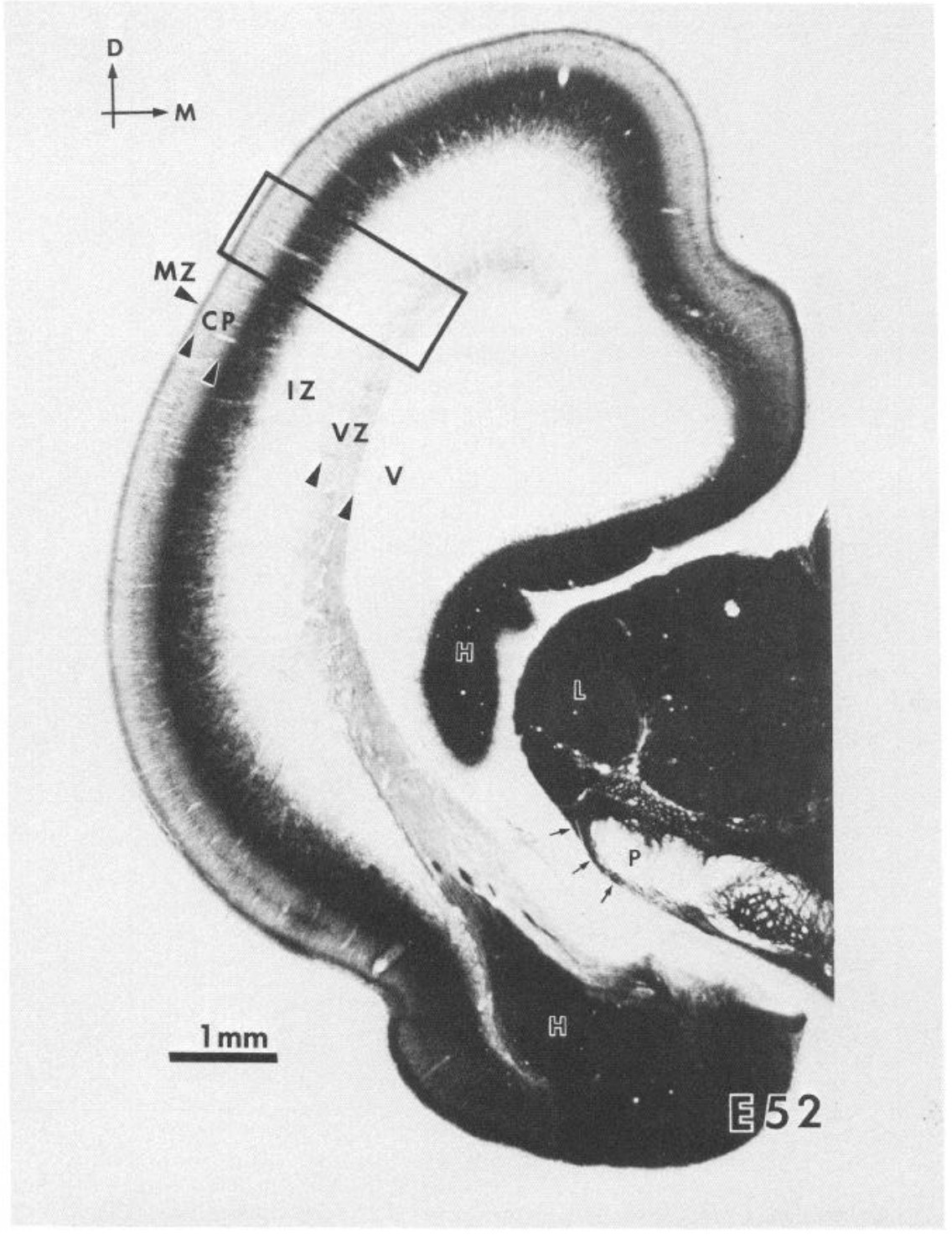

bined into bins of $60 \mu \mathrm{m}$ (combining 3 consecutive $20 \mu \mathrm{m}$ windows). This method of counting was repeated for each of the immunostained sections of interest, and the resulting data were plotted as histograms (see Figs. 12, 13).

\section{Results}

The results are presented in 3 parts. First, the pattern of MAP2 immunostaining is shown, along with its relationship to the subplate and marginal zones within fetal regions of the neocortex. The identity and morphology of the MAP2-immunostained elements within the subplate and marginal zone are also examined. Next, the GABA-, NPY-, SRIF-, and CCK-immunoreactive cells within the subplate and marginal zone are shown to belong to the early-generated population, and their morphologies and distributions are examined. Finally, changes in the subplate with development are examined.

\section{Relation of MAP2 immunoreactivity to early-generated cells}

We first used the neuron-specific marker MAP2 to examine the organization of the fetal neocortex. An example of a section immunostained for MAP2 at E52 is shown in Figure 3. Most of the major embryonic zones as previously defined (Boulder Committee, 1970) are indicated, including the outermost marginal zone (MZ: future cortical layer 1), the subjacent cortical plate (CP: future cortical layers 2-6), the intermediate zone (IZ: future white matter), and the ventricular zone (VZ: future ependymal zone). The heaviest stain within the neocortex is located within the marginal zone and the more superficial part of the intermediate zone, and staining extends rather uniformly throughout the entire hemisphere. This pattern is observed in all regions of the brain examined (from the frontal lobe to the posterior pole). Some immunostaining is also just visible in the deep intermediate zone and the ventricular zone as well as within the cortical plate.

What are the MAP2-immunoreactive elements of the marginal zone and subplate? At least some, if not most, are the earliest-generated cells of the neocortex along with their processes. This point is demonstrated by combining ${ }^{3} \mathrm{H}$-thymidine autoradiography following an injection at E27 with MAP2 immunohistochemistry at E56, as shown in Figure $4 A$ : every ${ }^{3} \mathrm{H}$ thymidine-labeled cell is also MAP2 immunostained. In fact, it 

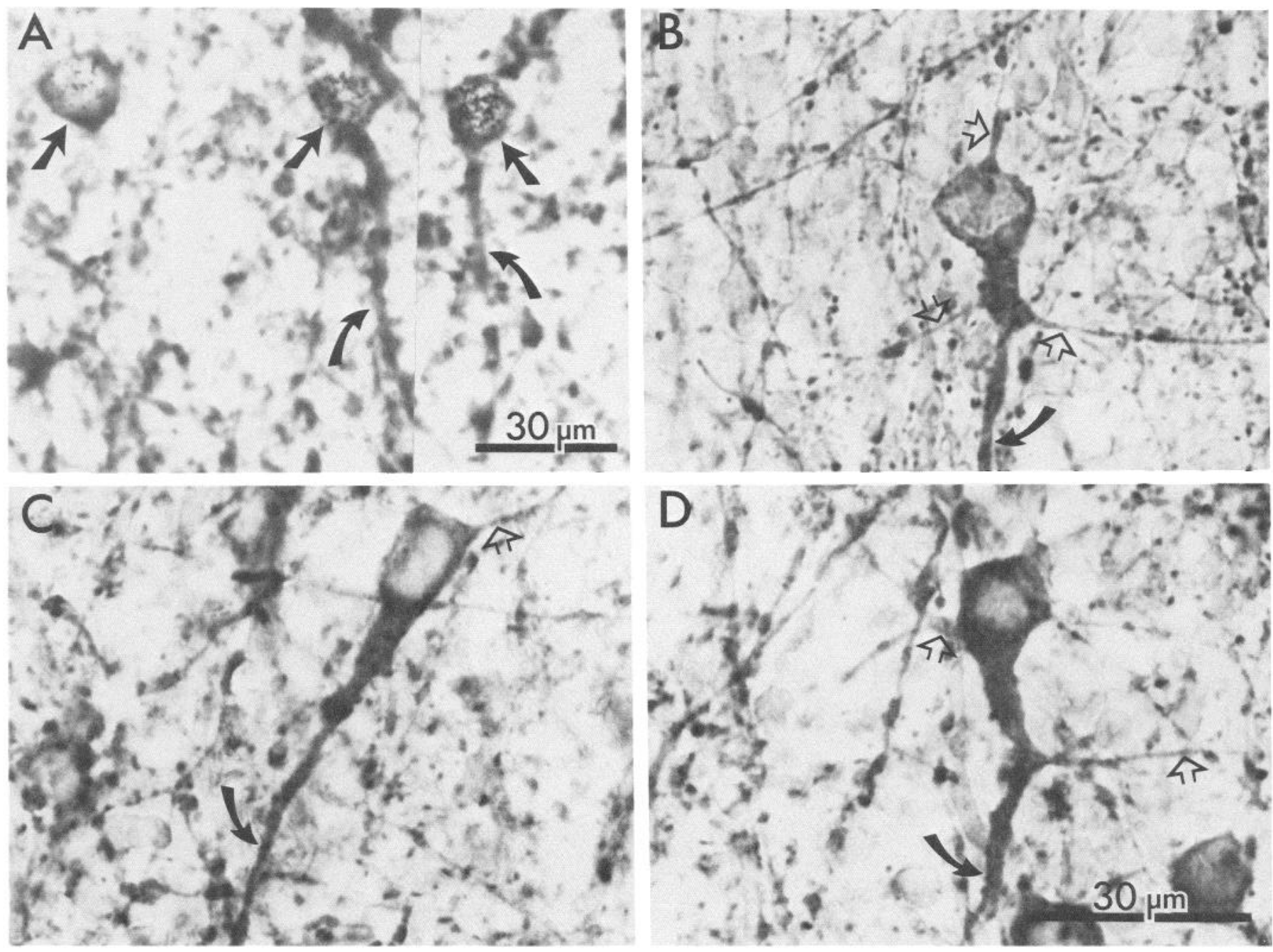

Figure 4. MAP2 immunostaining reveals a variety of subplate neuron morphologies. E56 brain previously labeled with ${ }^{3} \mathrm{H}$-thymidine at E28 was immunostained with MAP2. A, Examples of autoradiographically labeled subplate neurons and their MAP2 morphologies are shown from a cryostat section (straight arrows: silver grains over nuclei; curved arrows: MAP2-immunoreactive processes). $B-D$, Morphologies of subplate neurons at E56 from Vibratome sections. A major process is often directed towards the ventricle as indicated (curved arrows); ventricle towards the bottom of the page. Note that other processes extend from various portions of the subplate neuron in many directions (open arrows). Scale bar for $B-D$ is shown in $D$.

was rare to find ${ }^{3} \mathrm{H}$-thymidine-labeled cells not also labeled by MAP2 in these double-label experiments, suggesting that many, if not all, of the early-generated cells residing in the subplate are neurons (see also Chun and Shatz, 1988a). Further, Figure $4, B-D$ shows that many MAP2-stained cells have a major dendrite extending towards the ventricular zone as well as many other dendritic processes. Note that many of the processes are beaded and that MAP2-immunoreactive processes virtually fill the field of each micrograph. These observations confirm our previous demonstration that many, if not all, of the early-generated cells are likely to be neurons (Chun et al., 1987). Moreover, the MAP2 immunostaining seen in the upper region of the intermediate zone in Figure 3 is associated with the somata and elaborate processes of the subplate neurons.

MAP2 immunostaining within the marginal zone is also directly associated with the early-generated cells, as shown in Figure $5 A$, where combined ${ }^{3} \mathrm{H}$-thymidine birthdating at E28 and MAP2 immunohistochemistry at E52 are combined. The MAP2-immunoreactive processes are often horizontally di- rected (Fig. 5, B, C). As in the subplate, many processes within the marginal zone are also beaded.

The MAP2-immunoreactive subplate and marginal zone thus appear to reflect the presence of the early-generated subplate and marginal-zone neurons themselves. Further, the elaborate processes of these neurons contribute to the complexity observed throughout both regions. In view of this conclusion, it seems reasonable to suggest that the lower border of the subplate can be defined as the region of the intermediate zone in which MAP2 immunostaining becomes rather sparse. This point is illustrated in Figure 6, which compares the relationship between MAP2 immunostaining and the histological organization of the cerebral wall as revealed in a cresyl-violet-stained section. We shall therefore refer to the thick band of MAP2 immunostaining beneath the cortical plate as the subplate.

On the other hand, MAP2 immunostaining alone (particularly at older fetal ages) cannot be used to determine accurately the upper border between the subplate and the cortical plate, because neurons belonging to cortical layers 5 and 6 become im- 
Figure 5. MAP2 immunostaining reveals a range of marginal-zone neuron morphologies. $A$, Autoradiographically labeled MAP2-immunoreactive marginal-zone neuron is shown for a brain immunostained for MAP2 at E56 after being labeled with ${ }^{3} \mathrm{H}$-thymidine at E28 (straight arrow: silver grains; curved arrows: MAP2). $B, C$, Horizontal processes (curved arrows) of these neurons from an E52 brain. Some processes make more extreme curves within the marginal zone (small arrows in $C$ ). Pial surface towards the top of the page.

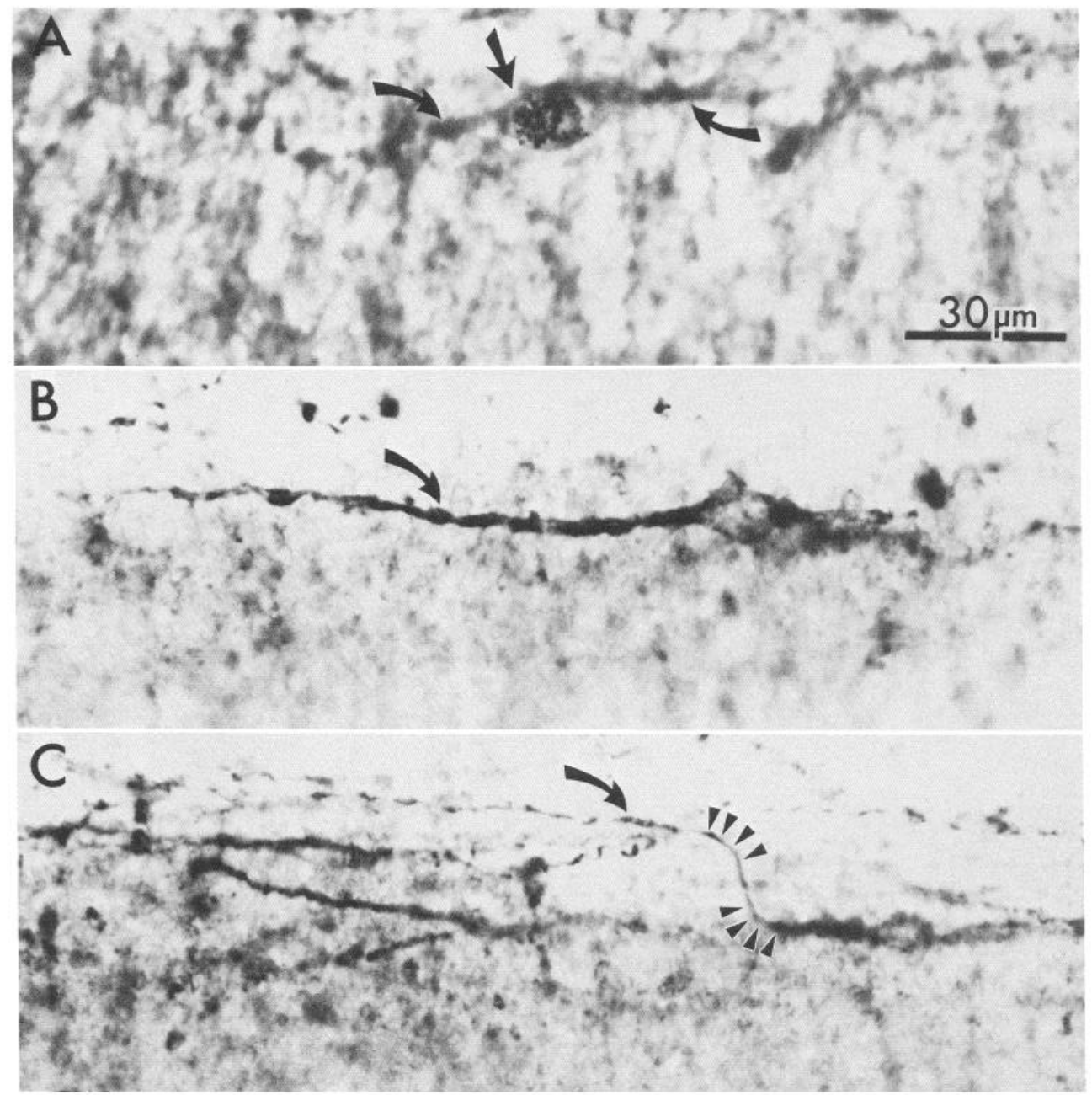

munoreactive as they mature. The border can be determined with accuracy, however, by using ${ }^{3} \mathrm{H}$-thymidine birthdating of the subplate neurons at E28-30 (when the most superficial subplate neurons are generated; see Luskin and Shatz, 1985a). For example, Figure 7 shows adjacent cryostat sections processed for MAP2 immunohistochemistry (Fig. 7A) and autoradiography (Fig. $7 B$ ). Note that the zone of ${ }^{3} \mathrm{H}$-thymidine-labeled cells coincides with a region of MAP2 immunostaining that is in transition between the orderly staining of pyramidal cells at the base of layer 6 and the more complex pattern of staining within deeper regions of the subplate.

\section{Relationship between GABA- and neuropeptide- immunoreactive cells and the early-generated neurons}

To further characterize the subplate and marginal-zone neurons and to learn more about their detailed morphology we immunostained sections from the fetal brain with antibodies against NPY, SRIF, CCK, and GABA. This choice of antibodies was motivated by studies of the adult cerebral cortex indicating that part of the small population of neurons known to be present in the white matter is immunoreactive for some of these neuropeptides (SRIF: Bennett-Clarke et al., 1980; Finley et al., 1981; Sorensen, 1982; Hendry et al., 1984a; Schmechel et al., 1984; Somogyi et al., 1984; Laemle and Feldman, 1985; NPY: Adrian et al., 1983; Allen et al., 1983; Hendry et al., 1984a; Chan-Palay et al., 1985; CCK: Innis et al., 1979; Hendry et al., 1983; Somogyi et al., 1984; GABA or GAD: Ribak, 1978; Hendrickson et al., 1981; Schmechel et al., 1984; Somogyi et al., 1984; Wahle et al., 1987) and by the results of our preliminary studies suggesting that some of the early-generated neurons are immunoreactive for these particular transmitters (Chun et al., 1987).

Figure 8 shows that subplate cells labeled at E27 with ${ }^{3} \mathrm{H}-$ thymidine can also be immunoreactive for GABA (Fig. 8, $A$ $C$; marginal-zone neurons can also be labeled), NPY (Fig. 8, $D$ $F$ ), SRIF (Fig. 8, $G-I$ ), or CCK (Fig. $8, J, K$ ) when stained in later fetal (or neonatal for CCK) life. In addition to the doublelabeled cells present in the cryostat sections shown in Figure 8, each experiment also shows that not all cells generated at the same time can be immunostained with a given neuropeptide antibody (e.g., Fig. 8, E, G, arrows). The converse was also true: not all immunostained cells were ${ }^{3} \mathrm{H}$-thymidine labeled. This observation is consistent with the fact that ${ }^{3} \mathrm{H}$-thymidine is available for only about $2 \mathrm{hr}$ after delivery, whereas the entire population of subplate and marginal-zone neurons are generated over a 1-week period between E24 and E30 (Luskin and Shatz, $1985 \mathrm{a}, \mathrm{b})$. Thus, only a small fraction of the entire population will be autoradiographically labeled following a single injection at E27. As discussed further below, CCK-immunoreactive cells 


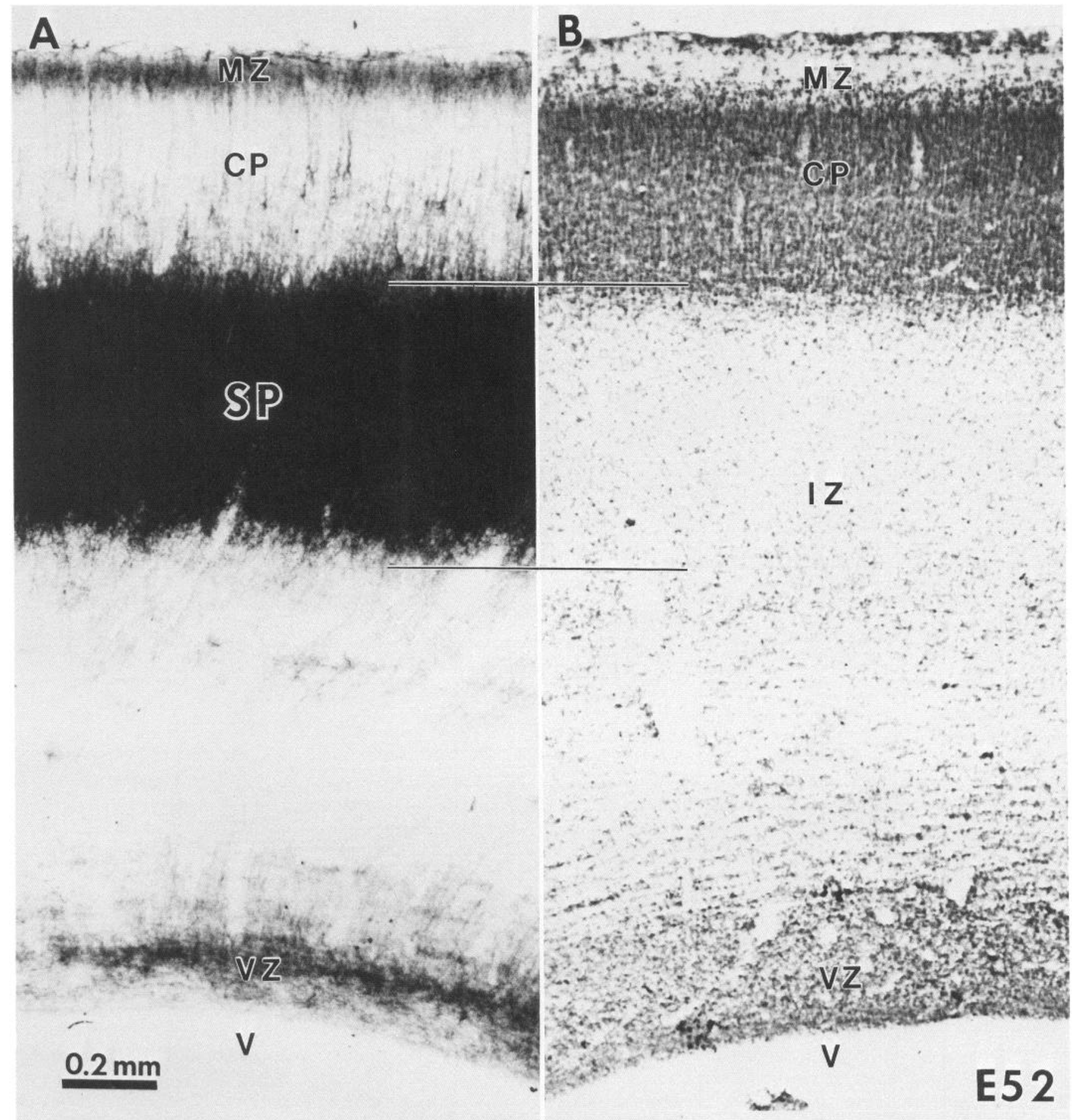

Figure 6. Relationship of MAP2 immunostaining to the histological organization of the cerebral wall at E52. A, Enlargement of a region similar to that shown in Figure 3 (rectangle). $B$, Adjacent section stained with cresyl violet to show the location of cell bodies. The lines divide the section into the conventional fetal zones: the marginal zone $(M Z$; future layer 1$)$, the cortical plate ( $C P$; future cortical layers $2-6)$, the intermediate zone (IZ; future white matter), and the cell germinal region called the ventricular zone ( $V Z$; future ependyma). At this age, MAP2 prominently stains the marginal zone, a few pyramidal neurons in the cortical plate, and a large region beneath the cortical plate that extends through a good portion of the intermediate zone: we have called this entire region of dense MAP2 immunoreactivity the subplate (SP). Thus, the subplate occupies approximately the upper half of the intermediate zone. See text for further details. 
Figure 7. Upper border of the subplate as defined by ${ }^{3} \mathrm{H}$-thymidine birthdating of subplate neurons. Subplate neurons birthdated at E28 are the most superficial members of this transient population (Luskin and Shatz, 1985a). They can be identified autoradiographically at later dates (E56 in $B$; silver grains over nuclei appear white in this darkfield photograph). When compared to an adjacent section of brain immunostained for MAP2 $(A)$, the boundary between upper subplate $\left(S P_{U}\right)$ and the later-generated neurons of cortical layer 6 can be accurately determined. $C P$, Cortical plate; $S P$, subplate.

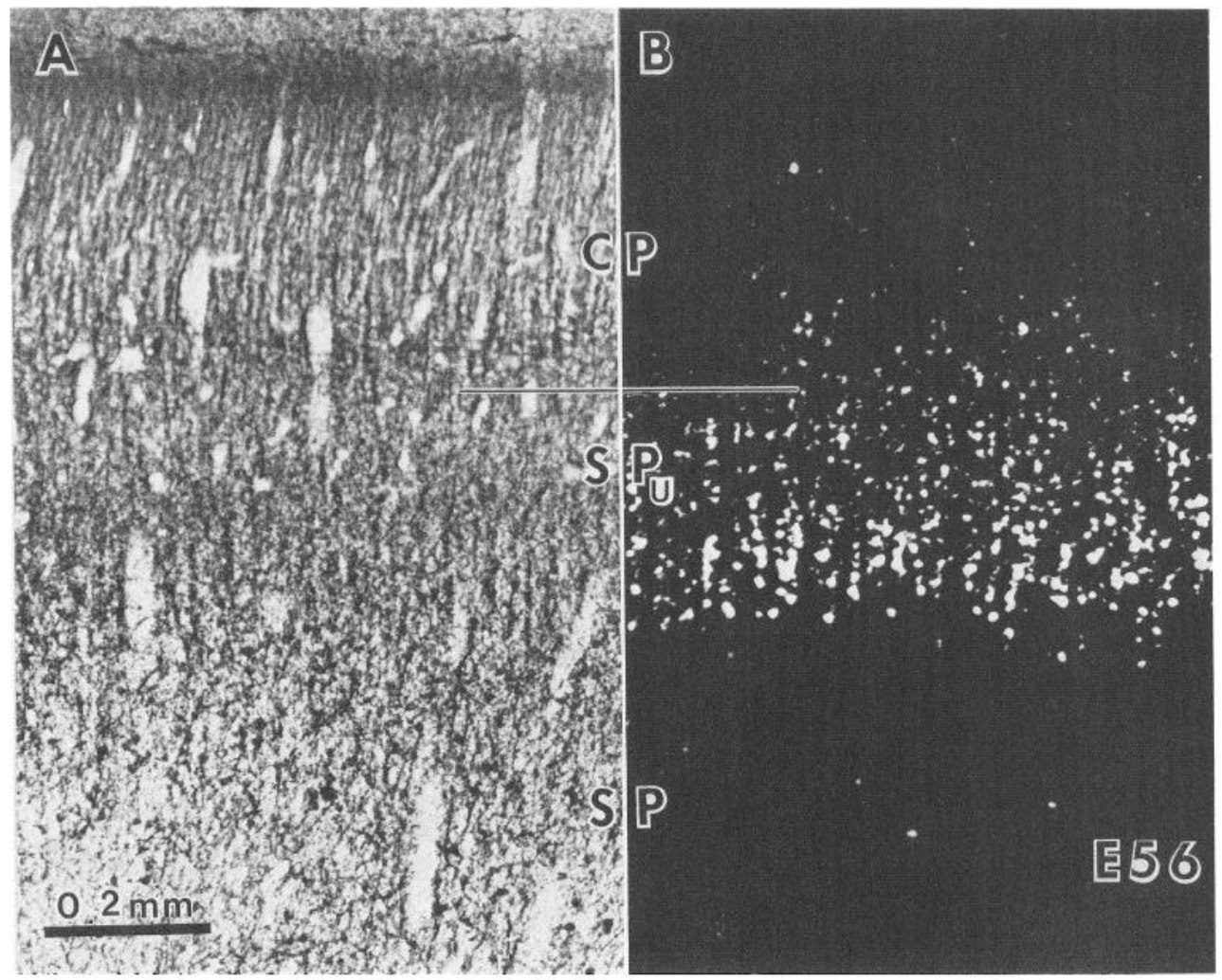

were not observed until the last week of gestation, when they are located predominantly within the marginal zone.

The morphology of the immunostained subplate neurons can be more fully appreciated in Vibratome sections as shown in Figure 9. Two common features are the presence of thick processes-probably dendrites-often directed towards the ventricular surface (cf. Fig. 4), and fine, long processes, often directed towards the pial surface. NPY-immunoreactive cells frequently have such a process, probably an axon, that loops towards the pial surface (Fig. 9, D, E).

The morphologies revealed by NPY and SRIF immunostaining can be seen more clearly in camera lucida drawings of fetal neurons such as those shown in Figure 10. The morphologies of NPY-immunoreactive neurons are shown at E54 in Figure $10 \mathrm{~A}$ (the long process extends from the subplate to the marginal zone), and those of SRIF-immunoreactive neurons are shown at E56 in Figure 10B. These examples illustrate the elaborate and varied appearance of subplate neurons. Thus, the results presented above demonstrate that subplate neurons as identified by ${ }^{3} \mathrm{H}$-thymidine birthdating can achieve a high degree of morphological maturity prior to birth and can be immunoreactive for GABA, NPY, SRIF, and CCK, whereas the marginal-zone neurons can be immunoreactive for CCK and GABA. We also have found that at least some of the SRIF-immunoreactive neurons within the subplate are also immunostained by GABA (J. Chun and C. Shatz, unpublished observations), consistent with the colocalization of this neuropeptide with GABA as reported in adult cells of the white matter (Hendry et al., 1984b; Somogyi et al., 1984).

\section{Variation and developmental changes in the subplate}

The immunohistochemical observations described above suggest that the subplate (and also the marginal zone) is an elaborate neuropil consisting primarily of the somata and a dense network of processes belonging to the early-generated subplate neurons, some of which are also GABA- and neuropeptide-immunoreactive. We were interested in examining whether there is any systemic relationship between the apparent transmitter phenotype of immunostained neurons and their location within the marginal zone or subplate during fetal life, particularly since we had previously noted the existence of such a relationship in the early postnatal cerebral cortex (Chun et al., 1987). To address this question, 3 consecutive sections through the medial wall of the lateral gyrus (future visual cortex) at E54 were immunostained for GABA, NPY, or SRIF (CCK-immunoreactive neurons are absent at this time; see Figs. 12 and 13), and the positions of all immunoreactive cells were plotted in camera lucida drawings. The 3 resulting drawings were superimposed as shown in Figure 11. (At this age, there were so many GABA-immunoreactive cells that only those present in the wedge illustrated have been drawn.) While GABA-immunoreactive cells do not appear to be clustered preferentially from pial to ventricular surface, SRIF-immunoreactive neurons are grouped predominantly within the upper subplate. NPY-immunoreactive neurons, in contrast, tend to be situated more deeply.

To confirm our impression that there is a relationship between particular peptide-immunoreactive neurons in the fetal neocortex and their laminar positions, we plotted the positions of 


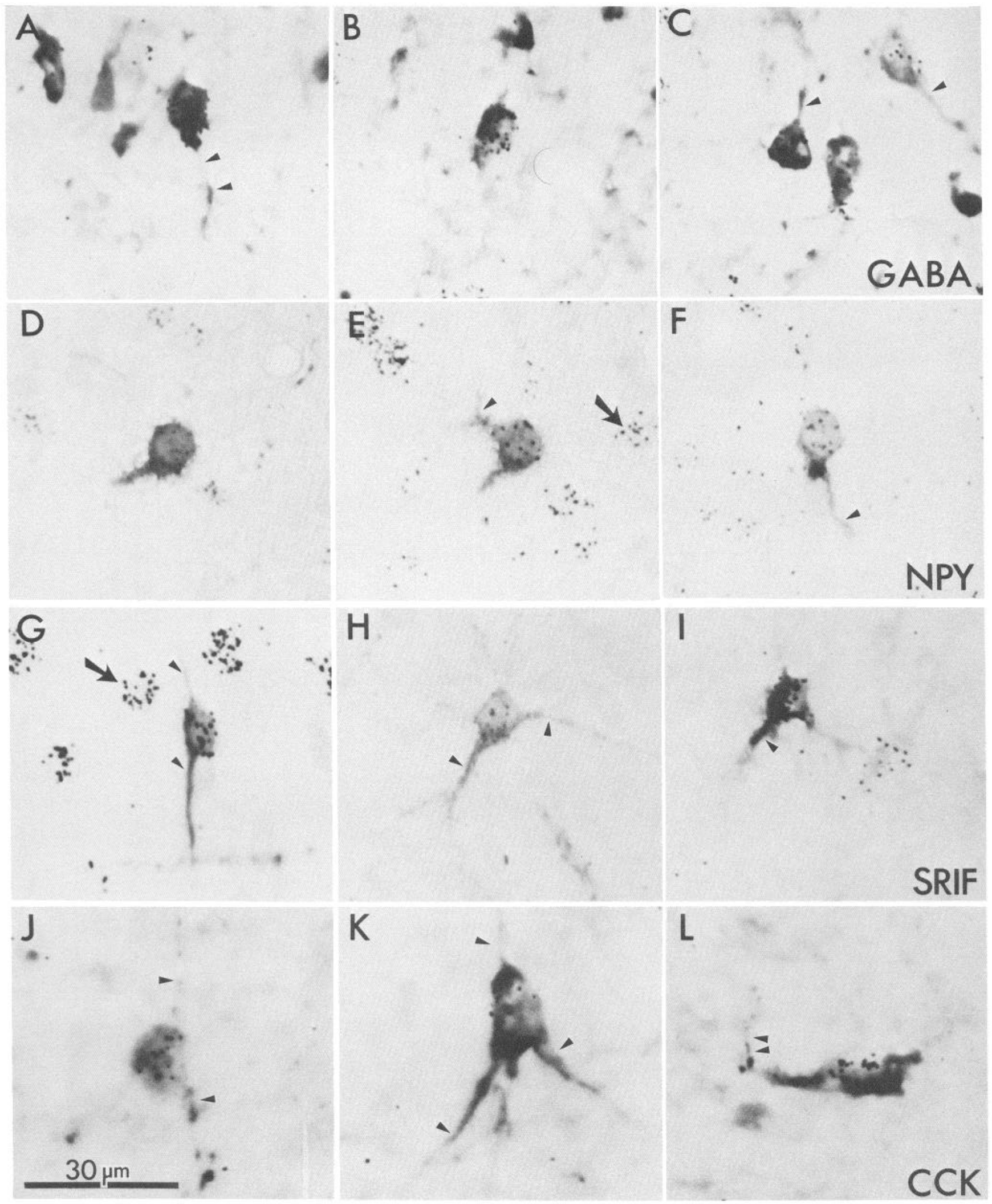

Figure 8. Early-generated neurons are also immunoreactive for GABA and various neuropeptides. Autoradiographically identified subplate neurons are immunoreactive for GABA $(A-C)$, NPY $(D-F)$, SRIF $(G-I)$, and CCK $(J, K ; L$, One marginal zone neuron is also shown). Some cell processes can be discerned in this cryostat-sectioned material (arrowheads). Examples of ${ }^{3} \mathrm{H}$-thymidine-labeled subplate neurons not immunoreactive for GABA or the neuropeptides examined were present in all experiments (e.g., straight arrows in $E$ and $G$ ). Subplate neurons were birthdated with ${ }^{3} \mathrm{H}$-thymidine at E27 and examined at E56 $(A-C, G-I)$, E54 $(D-F)$ and postnatal day $7(J-L)$. Pial surface towards top of page. 


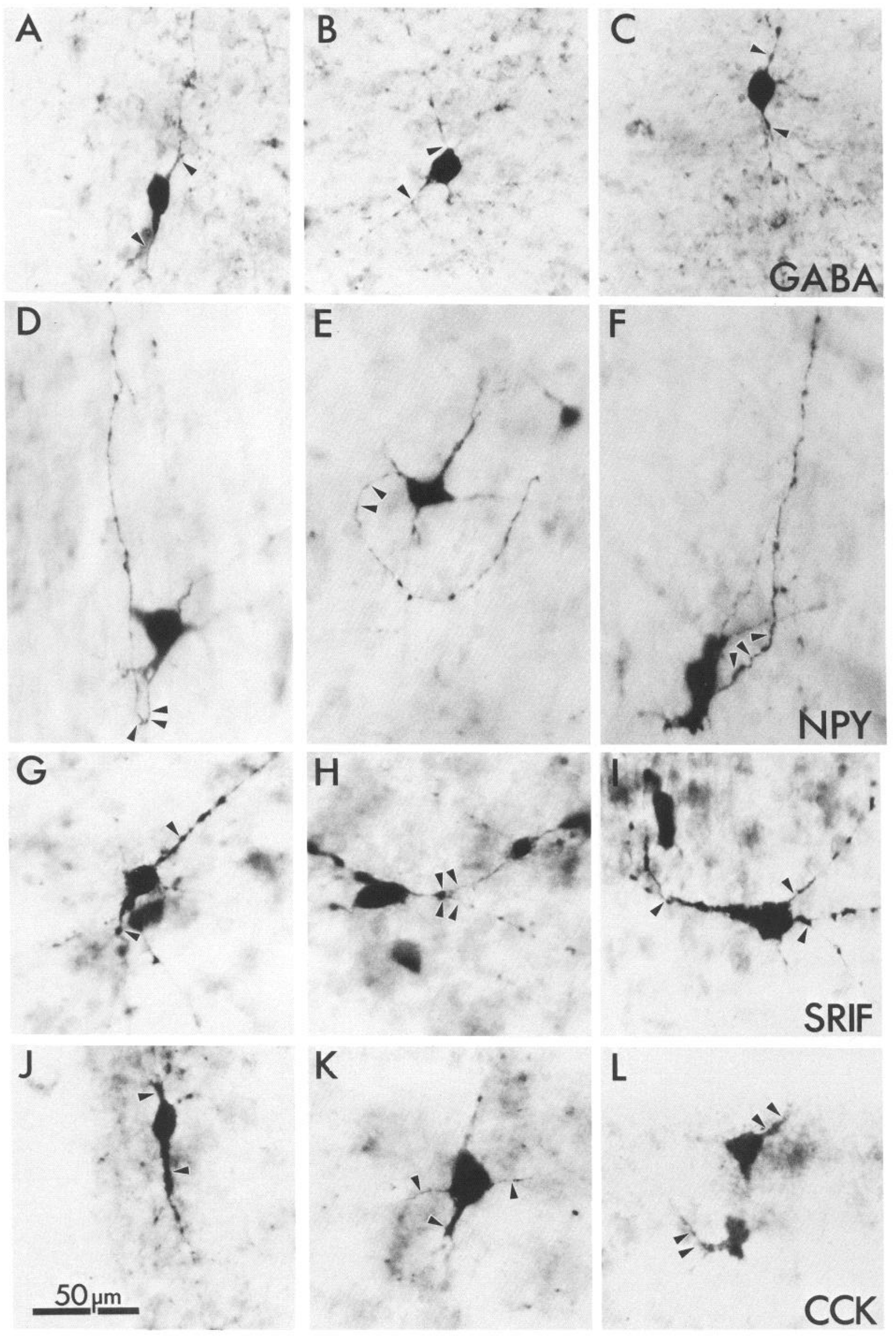


Table 3. Total numbers of cells, by age and immunoreactivity ${ }^{a}$

\begin{tabular}{|c|c|c|c|c|c|c|c|c|}
\hline \multirow[b]{2}{*}{ Age } & \multicolumn{4}{|c|}{ Visual cortex } & \multicolumn{4}{|c|}{ Temporal cortex } \\
\hline & $\overline{\mathrm{GABA}}$ & NPY & SRIF & CCK & $\overline{\text { GABA }}$ & NPY & SRIF & $\mathrm{CCK}$ \\
\hline E.50 & 2001 & 46 & 408 & & 1867 & 40 & 623 & \\
\hline E56 & 1076 & 20 & 162 & & 1338 & 25 & 205 & \\
\hline E60 & 1413 & 110 & 220 & 19 & 1066 & 145 & 502 & 29 \\
\hline
\end{tabular}

${ }^{a}$ See Figures 12 and 13 .

over 11,300 immunostained cells from the pial to the ventricular surface at E50, E56, and E60. Both the lateral gyrus (visual cortex; Fig. 12) and the ectosylvian gyrus (temporal lobe; Fig. 13; see Materials and Methods) were examined. The histograms of Figures 12 and 13 show the distribution of immunoreactive cells as a function of depth from the pial surface. The length of each bar in the histograms corresponds to the percentage of cells showing a particular transmitter or peptide immunorectivity at each $60 \mu \mathrm{m}$ step in depth (total numbers are shown in Table 3). At each age, and within both cortical areas, inspection of the histograms confirms the impression that GABA-, NPY-, SRIF-, and CCK-immunoreactive cells are not randomly distributed. First, the majority of the NPY- or SRIF-immunoreactive cells are not located in the cortical plate. Rather, especially at E50 and E56, cells tend to cluster in such a way that more of the NPY-immunoreactive cells are found deeper in the subplate, whereas the SRIF-immunoreactive cells are more concentrated at the border between the subplate and the cortical plate. Of the neuropeptides examined, only CCK-immunoreactive cells were found in the marginal zone, and only by E60. These cells also populate the deep subplate. However, the distribution of GABA-immunoreactive cells is more uniform, showing only a slight tendency to concentrate nearer the pial surface. In addition, a small percentage of cells with immunoreactivity for GABA, NPY, and SRIF is present surprisingly deep in the intermediate zone near and even within the ventricular zone. At least some, if not all, of these cells are also part of the subplate neuron population because they can be labeled by both ${ }^{3} \mathrm{H}$-thymidine birthdating at E26-28 and immunohistochemistry for MAP2, as well as for the neuropeptides and GABA.

A final issue is whether the dimensions of the subplate, as defined in this study using MAP2 immunohistochemistry, change during the fetal period studied here. Such a change is implied by Figures 12 and 13 . To assess quantitatively the change in the dimensions of the subplate relative to the cortical plate, a ratio of the areas of the 2 zones was calculated (see Materials and Methods). The results are shown graphically in Figure 14, in which the ratio of subplate to cortical plate area is plotted against the embryonic age (days). A value of 1.0 means that the structures have equal areas and therefore equal thicknesses. It should be noted that the increase in the ratio between E46 and E56 is duc to an increase in the thickness (from pial to ventricular surface) of the subplate, since the cortical plate does not become thinner (it actually becomes thicker) during this time.
The subsequent decrease in the ratio is due both to the continued growth of the cortical plate and to a less pronounced decrease in the thickness of the subplate. An analysis of the changes in the size of the marginal zone is difficult because the adult layer 1 is in many ways similar to the marginal zone, except for a loss of the marginal-zone neurons. Nevertheless, it is notable that the ratio of the marginal zone to the cortical plate area varies between 0.3 and 0.5 (i.e., equals $30-50 \%$ of the cortical plate area) during the developmental period shown in Figure 14.

The results of Figures 11-14 demonstrate that the subplate is not a homogeneous layer but rather is stratified with respect to cells expressing neuropeptide (and to a lesser extent, GABA) immunoreactivities. This phenomenon is present at several developmental ages in at least 2 distinct cortical regions. Further, the subplate increases in size between E46 and E56 but then decreases perceptibly by birth (E65), as documented by the change in the ratio of subplate to cortical plate area.

\section{Discussion}

The results of this study show that the two fetal zones containing the earliest postmitotic cells of the cerebral cortex are also rich in immunoreactivity for MAP2 (a neuron-specific protein) and for a variety of neuropeptides and GABA during development. As discussed below, we believe that, particularly at the earliest ages studied (E46-E56), most, if not all, of the MAP2 immunostaining in the subplate is directly associated with the earlygenerated cells. This conclusion is in agreement with the results of a previous study in which ${ }^{3} \mathrm{H}$-thymidine labeling in conjunction with MAP2 immunohistochemistry was used as part of the proof that the early-generated cells residing in the subplate are neurons (Chun et al., 1987). The present results demonstrating that there are distinct and extensive bands of immunostaining for MAP2 above and below the cortical plate throughout the neocortex during development suggest that the regions containing the early-generated population of neurons are much more elaborate and extensive than previously supposed.

The combined use of ${ }^{3} \mathrm{H}$-thymidine autoradiography with GABA and neuropeptide immunohistochemistry has also permitted us to show conclusively that some, if not all, of the cells located within the subplate and marginal zone that are immunorcactive for GABA, NPY, SRIF, or CCK are the carly-generated neurons, and that cells with different transmitter phenotypes tend to be located at different depths within the

Figure 9. Examples of fetal subplate neuron morphologies revealed by GABA and neuropeptide immunostaining. GABA ( $A-C$, at E56), NPY $(D-F$, at E54), SRIF $(G-I$, at E56), and CCK $(J, K ; L$ is from the marginal zone; E60). Multiple processes emanating from the cells can be seen in these Vibratome sections (small arrows). Some are directed towards the pial surface (towards top of page) and some branch (e.g., $H$ ). NPY morphologies are remarkable for the looping axons that are commonly present. Note that many of the processes are also beaded (cf. Fig. 4). 
1660 Chum and Shat - Earliest-Generated Neurons of Cat Cerebral Cortex
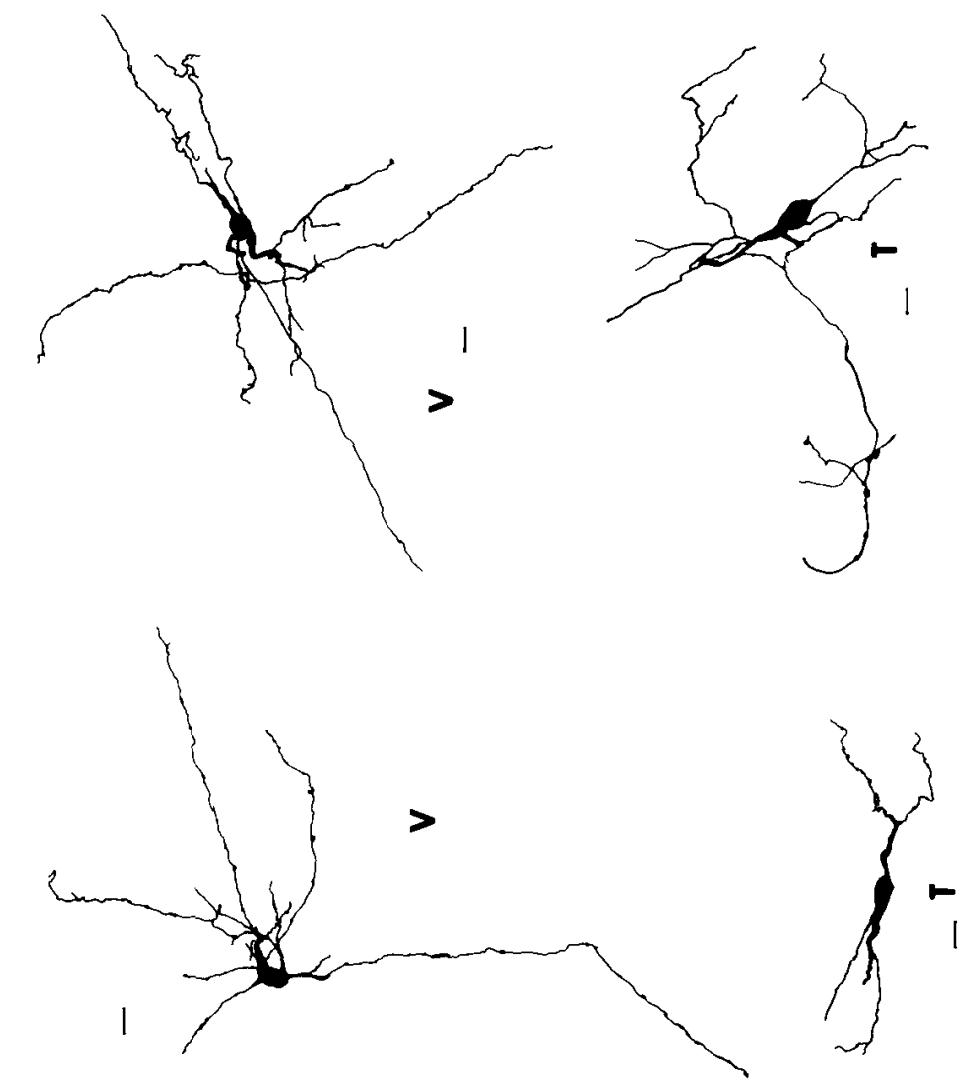
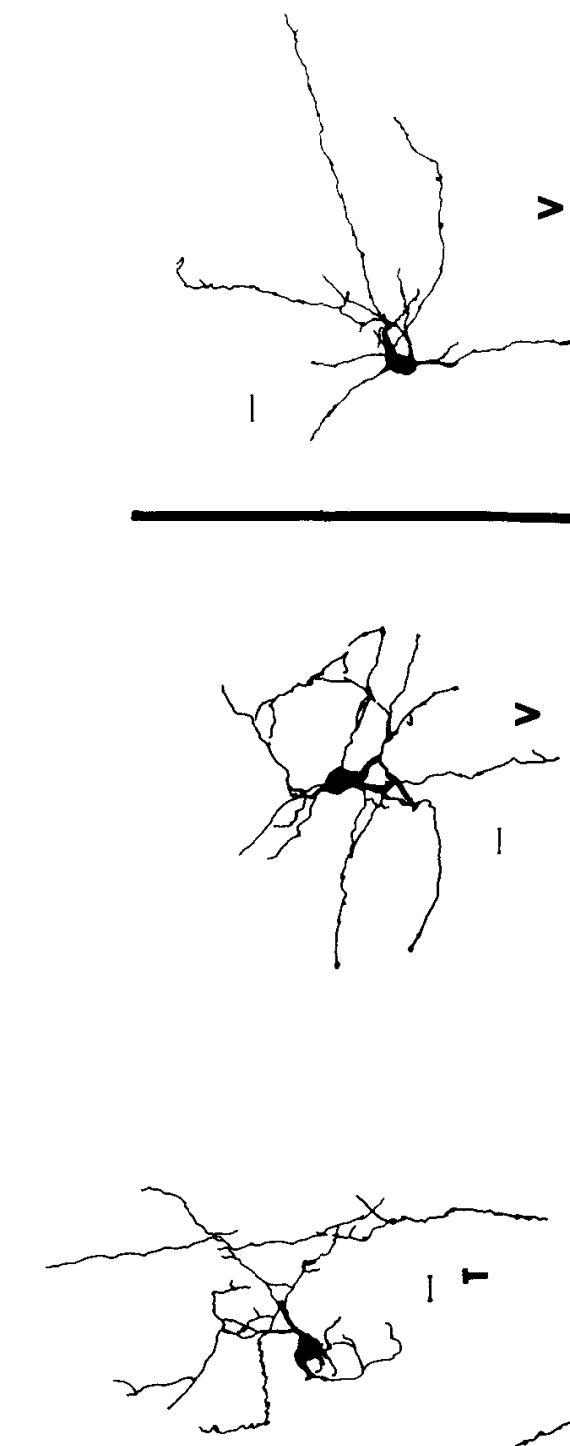

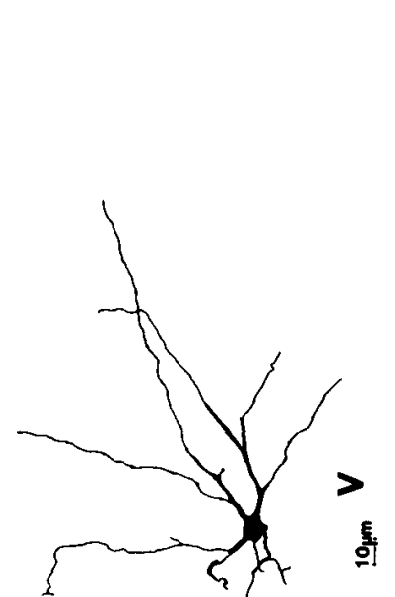

$\frac{u}{\tilde{s}}$

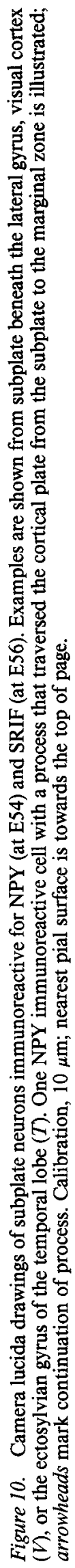




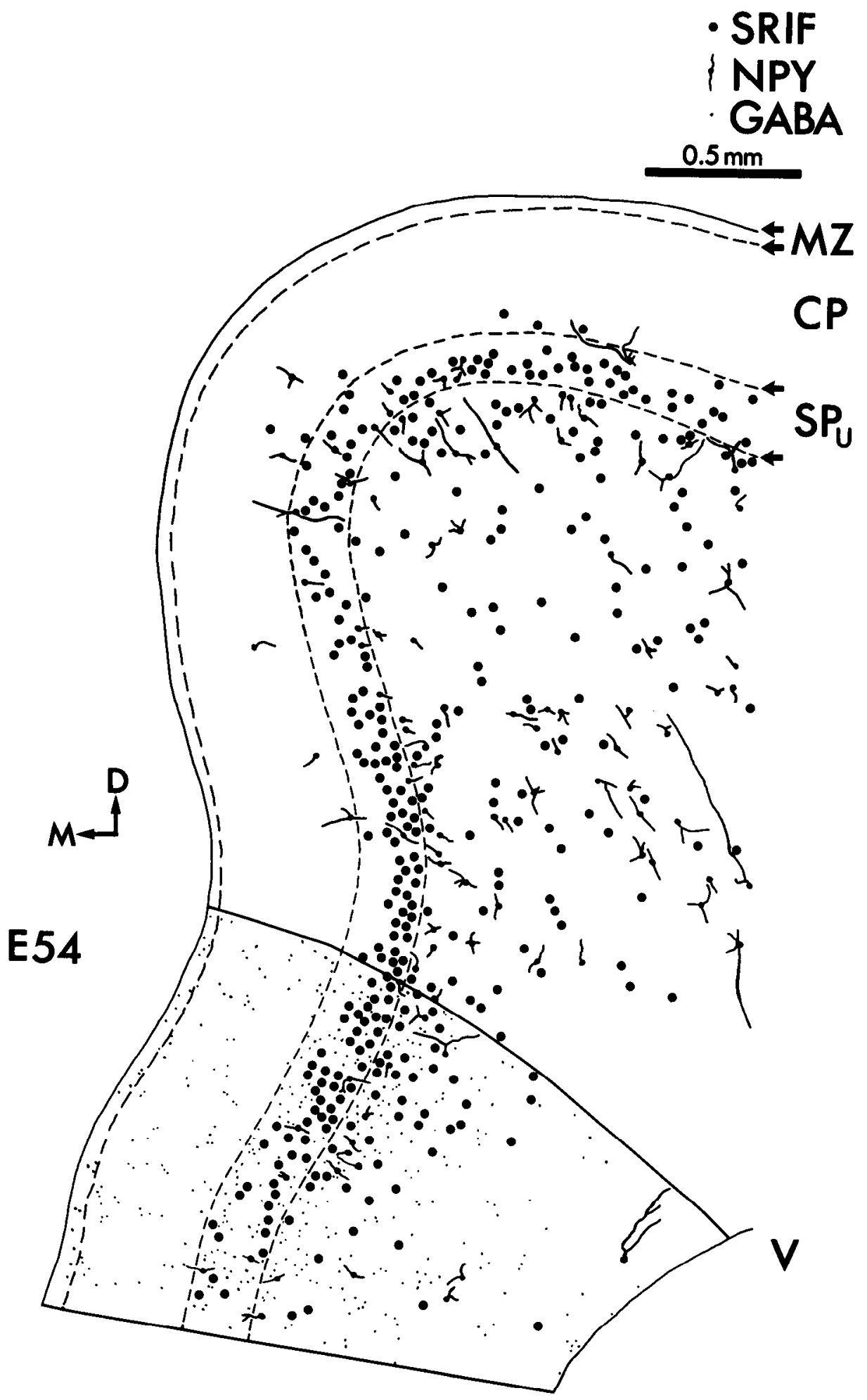

Figure 11. Distribution of GABA-, NPY-, and SRIF-immunoreactive neurons at E54. Camera lucida drawings were made from three adjacent sections. These were superimposed on a single drawing. (CCK-immunoreactive neurons are not present at this age.) Only a part of the GABA-immunoreactive population is presented (within delineated wedge). Note that while GABAimmunostained cells (small dots) are distributed rather uniformly across the cerebral wall, NPY-immunostained cells (dots with processes) generally appear to be located deeper in the subplate than SRIF-immunostained cells (large dots), which are concentrated in the upper part of the subplate $\left(S P_{v}\right)$. Note further that some cells of each immunoreactivity can be located near or within the ventricular zone $(V)$, while there are very few peptide-immunostained cells in the cortical plate $(C P)$ and the marginal zone (MZ). $D$, dorsal; $M$, medial.

tclenccphalic wall. Morcover, in vicw of the morphology and location of the cells examined here with immunohistochemical and birthdating techniques, we suggest that the previously observed Retzius-Cajal cells of the marginal zone are members of the early-generated population and that many of the Golgiimpregnated fetal neurons thought to reside at the base of the cortical plate are also part of the early-generated population.
However, previous ${ }^{3} \mathrm{H}$-thymidine birthdating studies in the cat have shown that the majority of early-generated neurons disappear by adulthood (Luskin and Shat7, 1985a; Chun and Shatz, 1989, and unpublished observations). Therefore, most neurons of the deep cortical plate thought from Golgi studies to be destined for cortical layer 6 in fact reside in the subplate and will disappear by adult life. 


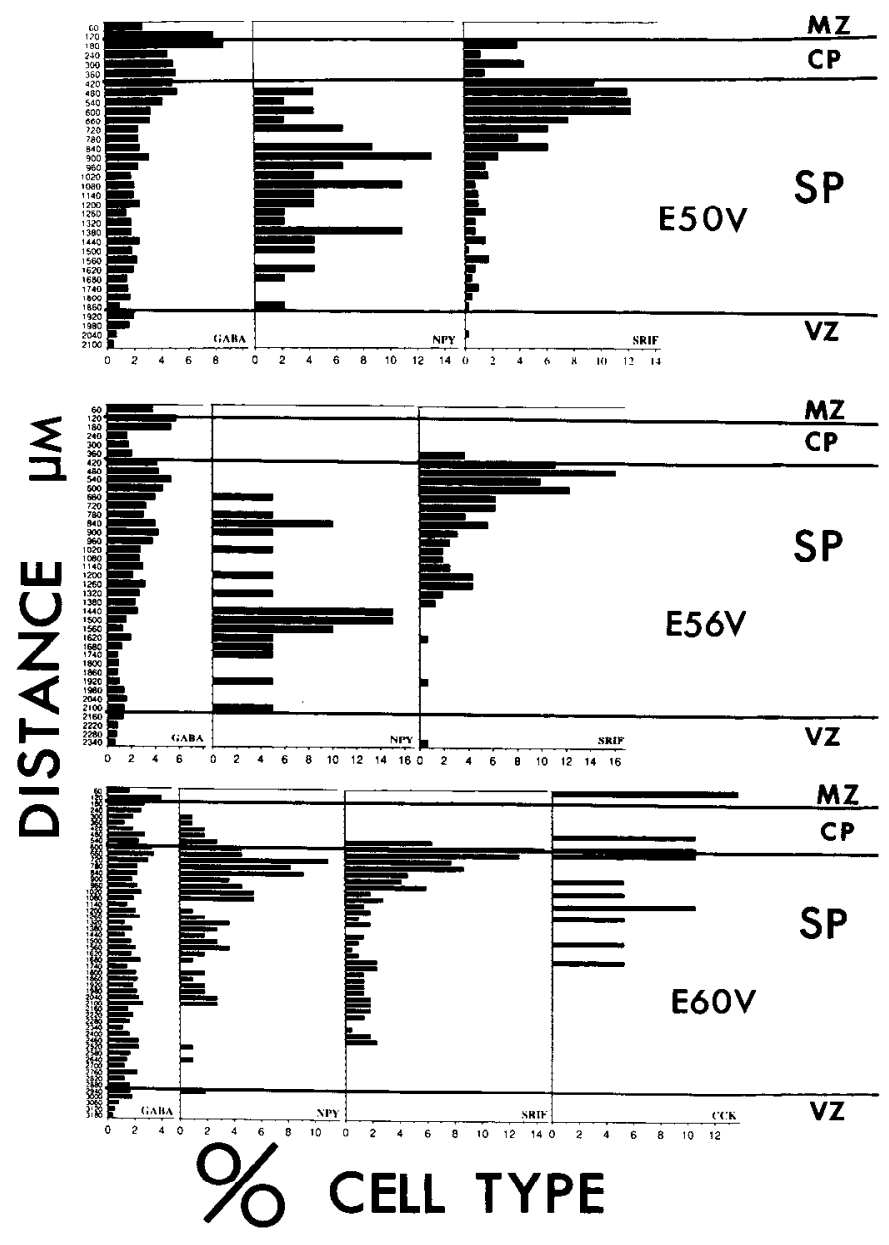

Figure 12. Differential location of immunoreactive cells from developing visual cortex at 3 different ages, as revealed by histograms. Distance in micrometers from the pial surface ( $\mathrm{Y}$-axis) versus the percentage of cells displaying each type of immunoreactivities is plotted. Note that the majority of the NPY-immunoreactive neurons reside deeper in the subplate $(S P)$ than do the SRIF-immunoreactive cells, which are predominantly within the upper subplate. GABA-immunoreactive cells are found throughout the telencephalic wall from pial to ventricular surface. CCK-immunoreactive cells are at their highest percentage in the marginal zone ( $M Z$; actual percentage, $31 \%$; off scale on graph) and deeper within the subplate. Note the presence of a few immunoreactive cells within the ventricular zone $(V Z)$. $C P$, Cortical plate. See Table 3 for more information.

\section{Technical considerations}

The validity of our results relies on several important methodological considerations. The first is that MAP2 is in fact neuron specific. Evidence for this point is extensive within both the adult (Matus et al., 1981; Miller et al., 1982; Vallee, 1982; Caceres et al., 1983, 1984; Bernhardt and Matus, 1984; De Camilli et al., 1984) and the developing (Bernhardt and Matus, 1982; Bernhardt et al., 1985; Crandall et al., 1986) nervous system, in which MAP2 immunostaining has been shown to be confined to the dendrites and sumata of neurons. That MAP2 was recognized in this study is supported by the presence of a MAP2-like molecule in Western blots, an identical immunostaining pattern produced by a polyclonal and a monoclonal antibody against MAP2, the absence of immunostaining from control sections, and the neuron-like morphologies of the immunostained cells. Because the vast majority of cells labeled by
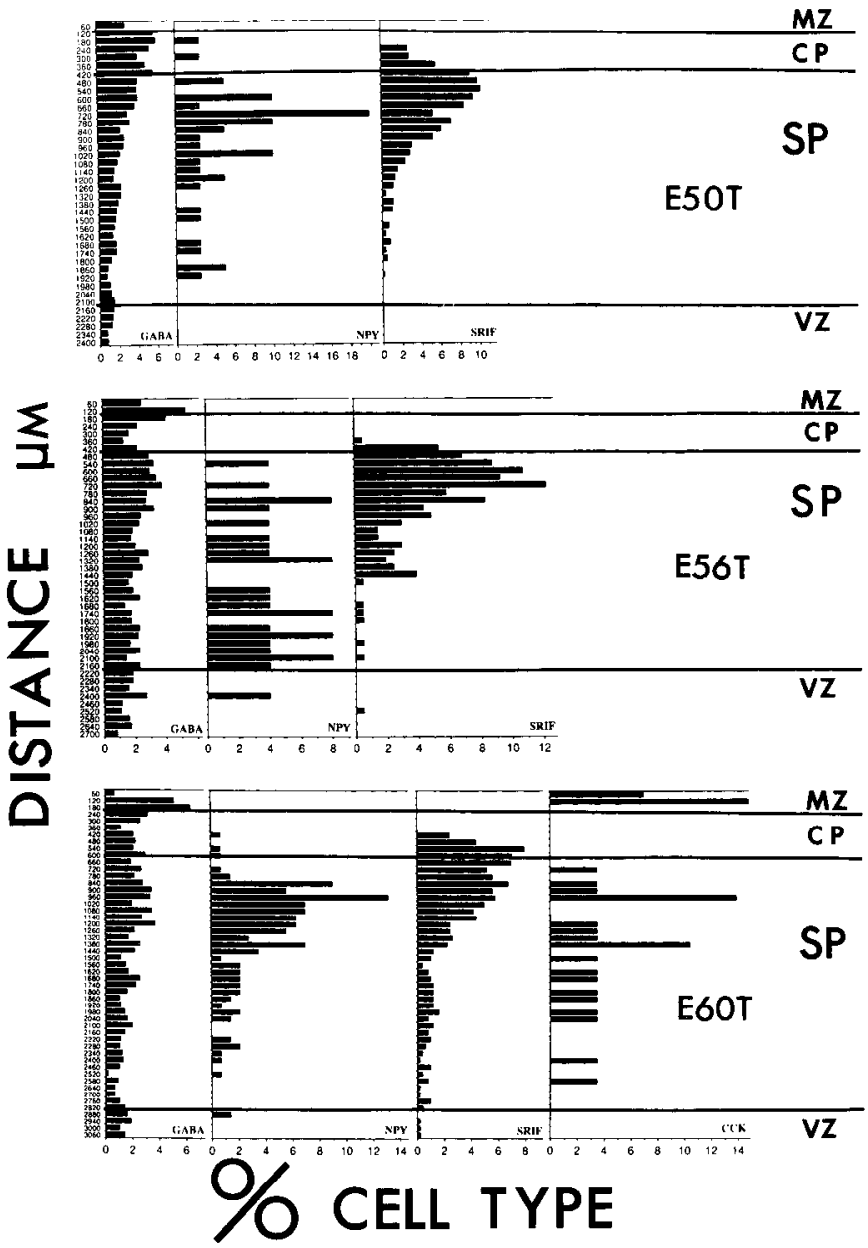

Figure 13. Differential location of immunoreactive cells from temporal cortex at 3 different ages. Note similarities with the analysis of visual cortex in Figure 12.

injections of ${ }^{3} \mathrm{H}$-thymidine before $\mathrm{E} 30$ were also MAP2-immunoreactive (see also Chun et al., 1987; Chun and Shatz, 1988a), it is highly likely that the majority of early-generated cells located in the subplate and marginal zone are neurons.

A second issue is the specificity of immunostaining for the neuropeptides and GABA. Although we cannot be certain that the antibodies actually recognize these transmitters in tissue section, the results of both normal serum and blocking controls suggest that the employed antisera are specific for their respective molecules. The morphologies of the immunostained cells also suggest that neurons are being recognized, a suggestion consistent with the fact that they can be double labeled with ${ }^{3} \mathrm{H}$-thymidine. However, although the morphology of the peptide-immunostained cells was distinctly neuronal, some of the GABA-immunoreactive cells might have been glia in view of their very small somata. These cells therefore were not included in the quantitative analysis of Figures 12 and 13.

A final point concerns the use of ${ }^{3} \mathrm{H}$-thymidine to uniquely label the early-generated population without labeling neurons of layers $2-6$. We administered ${ }^{3} \mathrm{H}$-thymidine by making a single intrauterine injection between E26 and E28. These ages are well within the period during which only subplate and marginalzone neurons are generated (Luskin and Shatz, 1985a, b). Moreover, ${ }^{3} \mathrm{H}$-thymidine is only available for uptake during approximately $2 \mathrm{hr}$ after the injection (Hickey et al., 1983), thereby 
assuring even greater time resolution. For these reasons we believe that the vast majority of ${ }^{3} \mathrm{H}$-thymidine-labeled cells studied here belong to the early-generated population.

\section{Organization of the subplate}

The boundaries of the subplate layer during development have not been clearly defined, leading to discrepancies in its exact location (cf. Kostovic and Molliver, 1974; McConnell, 1988). Moreover, as discussed more fully in the next section, the subplate neurons themselves have frequently been considered as part of the developing cortical plate (Astrom, 1967; Molliver and Van der Loos, 1970; Marin-Padilla, 1971, 1972; Derer, 1974) or, alternatively, as a distinct layer that becomes layer $6 \mathrm{~b}$ or 7 in the adult (Sugita, 1917; Konig et al., 1975; Rickmann et al., 1977; Marin-Padilla, 1978; Kaedler and Raedler, 1978; Raedler et al., 1980). We believe that the results presented here and elsewhere (Kostovic and Molliver, 1974; Rakic, 1977; Kostovic and Rakic, 1980, 1984; Luskin and Shatz, 1985a; Chun and Shatz, 1989) favor the interpretation that the subplate and the subplate neurons are distinct from the cortical plate and, further, that the subplate is a transient structure, with only a remnant surviving into adulthood as the interstitial neurons of the white matter (Kostovic and Rakic, 1980; Chun and Shatz, 1989).

We have presented evidence that the distribution of MAP2 immunostaining can be used to define the subplate layer. The layer includes, at its superficial border, the neurons of the upper subplate (defined by ${ }^{3} \mathrm{H}$-thymidine labeling of the most superficial subplate neurons; Fig. 4 and Luskin and Shatz, 1985a). The deep border varies with age, but because the majority of early-generated subplate neurons and their processes are confined to the zone of heavy MAP2 immunoreactivity, it is reasonable to propose that this deep border coincides with the region of abrupt decrease in MAP2 immunostaining. This is not to say that there are no subplate neurons located more deeply; on the contrary, we have shown here that some are present even in the ventricular zone, but they are few in number.

A related issue is whether the MAP2 immunostaining within the subplate reflects only the presence of subplate neurons and their processes or whether some immunostaining is also associated with the distal dendrites of layer 6 neurons or even more superficial layers. We think this is unlikely both in view of the morphologic evidence presented here and because elimination of subplate neurons by neurotoxins greatly reduces MAP2 immunostaining of the subplate while the cortical plate remains intact (Chun and Shatz, 1988a). These considerations indicate that the subplate as defined using a combination of MAP2 immunohistochemistry and ${ }^{3} \mathrm{H}$-thymidine autoradiography is a structure in its own right consisting of the transient subplate neurons. It is distinct from the cortical plate.

\section{Previously described fetal cortical neurons are early-generated}

The unambiguous location and horizontal morphologies of some of the marginal-zone neurons seen here using MAP2, CCK, and GABA immunostaining strongly suggest that these neurons are identical with the well-known Retzius-Cajal cell of Golgi studies (Ramón y Cajal, 1891; Retzius, 1891, Astrom, 1967; Stensaas, 1967a-d; Sas and Sanides, 1970; Baron and Gallego, 1971; Marin-Padilla, 1971, 1972; Marin-Padilla and Marin-Padilla, 1982; Konig et al., 1975, 1981; Raedler and Sievers, 1976; Bradford et al., 1977; Raedler and Raedler, 1978; Edmunds and Parnavelas, 1982; Parnavelas and Edmunds, 1983). The situation with

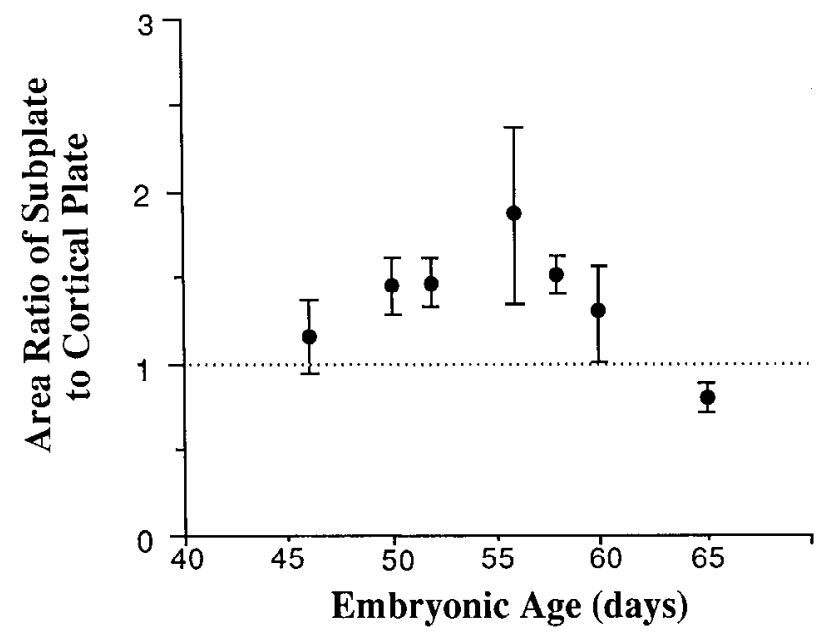

Figure 14. Quantitative description of the progressive change in the size of the subplate relative to the cortical plate. Ratio of subplate to cortical plate area was constructed at E46, E50, E52, E56, E58, E60, and E65 (birth). (See Materials and Methods for details.) Note that the 1.0 line marks the value at which the 2 areas are equal and that the ratio reaches its largest value at around E56. Because the cortical plate actually increases in thickness from E46 to E56, the increasing ratio reflects a marked increase in the thickness of the subplate. This trend reverses itself after E56, so that the ratio at birth is approximately $50 \%$ of the peak value.

respect to the subplate neurons is less clear because many previous morphological studies (Kolliker, 1896; Cajal, 1911; Lorente de No, 1933; Godina, 1951; Astrom, 1967; Stensaas, 1967a-d; Marin-Padilla, 1971, 1972) were not able to make the critical distinction between layer 6 of the cortical plate and the subplate. As we have shown here and in previous studies (Luskin and Shatz, 1985a; Chun et al., 1987; Chun and Shatz, 1988a, b), to do so requires the use of ${ }^{3} \mathrm{H}$-thymidine autoradiography to mark unambiguously the zone of early-generated cells that we know does not persist into adult life (see Luskin and Shatz, 1985a, b; Chun and Shatz, 1989). Thus, many earlier studies assumed that neurons situated within or at the top of the intermediate zone were part of the cortical plate (layer 6) rather than the transient subplate. For example, in the particularly beautiful Golgi studies of the developing fetal neocortex, Astrom (1967, in sheep), Stensaas (1967a-d, in rabbit), Marin-Padilla (1971, 1972, in cat), and Lund et al. (1977, in monkey) described cells similar in morphology to those observed here. We suggest that at least some of the cells observed in these Golgi studies, including the stellate and Martinotti cells of Astrom (1967) and the Martinotti and pyramid-like cells of Marin-Padilla (1972), are in fact early-generated subplate neurons, most of which disappear by adulthood (Chun et al., 1987; Chun and Shatz, 1989). Golgi-impregnated cells with horizontal processes located within the fetal white matter (Stensaas, 1967c, d; Rickmann et al., 1977, in rat), are also likely to be subplate neurons. However, as mentioned above, proof that these Golgi-impregnated cells are subplate neurons requires the combined use of ${ }^{3} \mathrm{H}$-thymidine birthdating, a particularly critical requisite during development because the Golgi technique is not specific for neurons and does not provide any information about the time of neurogenesis.

Previous immunohistochemical studies of developing cortex have also described neurons with morphologies and locations similar to those described here for NPY (Foster and Schultzberg, 1984; Woodhams et al., 1985), SRIF (Cavanagh and Parna- 
velas, 1988; Naus et al., 1988, who have further identificd mRNA for SRIF), GAD or GABA (Wolff et al., 1984; Lauder et al., 1986; Wahle et al., 1987; see also Chronwall and Wolff, 1980), and early postnatal NPY and CCK (Wahle and Meyer, 1987; Meyer and Wahle, 1988). Our combined morphological and ${ }^{3} \mathrm{H}$-thymidine evidence shows that fetal white matter cells identified in the above studies are, at least in part, the early-generated subplate and marginal-zone neurons.

\section{Role of the subplate during development}

It has been suggested that the subplate is an ontogenetic remnant of neocortical evolution (Marin-Padilla, 1971). That is, during development the mammalian neocortex begins as a primordial plexiform layer resembling the adult amphibian, then reptilian cortex, and then through subsequent development, the mammalian organization emerges. While this is certainly a reasonable description, perhaps it is more informative to vicw the subplate as a structure that promotes a set of cellular and molecular interactions that are required for the formation of the adult 6-layered cerebral cortex. If so, it is necessary to consider the nature of such interactions (for a review, see Shatz et al., 1988).

One such interaction is that the subplate neurons could serve as temporary targets for ingrowing afferent systems. It is now well known that many ingrowing axonal systems (e.g., thalamocortical, callosal) wait within the subplate for days to weeks, depending on species before invading the cortical plate (Lund and Mustari, 1977; Rakic, 1977; Wise et al., 1977; Wise and Jones, 1978; Innocenti, 1981; Crandall and Caviness, 1984; Kostovic and Rakic, 1984; Shatz and Luskin, 1986). For example, in the cat's visual system geniculocortical axons appear to arrive within the subplate even before the birth of their principal targets, the neurons of cortical layer 4 (Shatz and Luskin, 1986). While these geniculocortical axons grow into the cortical plate by birth, callosal axons continue to wait in the subplate for some time thereafter (Wise and Jones, 1976; Innocenti, 1981; McConnell and Shatz, 1988), consistent with the fact that the subplate itself persists into postnatal life. (see Chun and Shatz, 1989). Moreover, it may also be significant that the decrease in relative thickness of the subplate seen here after E56 correlates well with the time that the geniculocortical axons appear to leave the subplate and invade the cortical plate (Shatz and Luskin, 1986). Marginal-zone neurons may play a similar role, because thalamocortical afferents are also present there in development (Lund and Mustari, 1977; LeVay et al., 1978; Parnavelas and Chatzissavidou, 1981; Kato et al., 1984; Shatz and Luskin, 1986).

The cellular interactions responsible for the waiting period are unknown, but one possibility is that the presence of subplate neurons creates a unique extracellular environment that somehow promotes the waiting of axons rather than growth into the cortical plate. It appears that the subplate (and marginal zone), but not the cortical plate, contains a fibronectin-like molecule during development (Stewart and Pearlman, 1987; Chun and Shatz, 1988a). Moreover, the expression of this molecule may be dependent on the presence of subplate neurons since eliminating them by neurotoxin treatment decreases fibronectin immunostaining, and the immunostaining normally disappears during development with the disappearance of the subplate neurons (Chun and Shatz, 1988a). These observations suggest that the subplate contains information that allows specific extracellular interactions necessary for cortical development.

Subplate neurons could also participate in a transient synaptic network during development. The results of many previous ultrastructural studies (Kostovic et al., 1973; Molliver et al., 1973; Kostovic and Molliver, 1974; Cragg, 1975; Konig et al., 1975; Kristt and Molliver, 1976; Wolff, 1976; Blue and Parnavelas, 1983) have shown that the first synapses during development are formed within the subplate and the marginal zones. Immunohistochemistry for synaptic vesicle antigens has further shown that the entire subplate is a transient synaptic zone during fetal life (Chun and Shatz, 1988b). The subplate neurons themselves appear to be the recipients of at least some of the synapses, as demonstrated by EM studies of HRP-labeled (Chun et al, 1987) or ultrastructurally identified (Valverde and Facal-Valverde, 1988) subplate neurons, and subplate neurons can make local or interhemispheric connections (Chun et al., 1987; J. J. M. Chun and C. J. Shatz, unpublished observations). While there is no conclusive proof, reasonable candidates for at least some of the presynaptic terminals include the waiting axons and the local and distant projections of the subplate neurons. Thus, all the elements required for a synaptic network are present, raising the possibility that it is functioning during fetal life. Support for this view comes from the known presence of at least one molecule that participates in presynaptic transmitter release (synapsin I; Chun and Shatz, 1988b). Moreover, evoked field potential or single unit recordings in neonatal cats (Purpura, 1961a, b; Purpura et al., 1965; Huttenlocher, 1967) and fetal sheep (Bernhard et al., 1959, 1967; Molliver, 1967; Meyerson and Persson, 1969) have suggested indirectly that the developing white matter is a site of synaptic interactions.

The fact that subplate neurons appear to contain neuropeptides and GABA suggests several other developmental roles in addition to those noted above. For example, there are now several studies in which neuropeptides or other transmitters have been implicated in controlling neurite outgrowth and growth cone motility in the invertebrate nervous system (Bulloch, 1987; Haydon et al., 1987), and it is conceivable that the peptides and/or GABA could have similar effects within the subplate and marginal zone. If so, then the observation here that there is a tangential organization of early-generated peptide-immunoreactive neurons within the fetal subplate and marginal zone could confer a measure of specificity on the interactions between axons and their proposed targets within the subplate: different sets of waiting axons could interact with different peptide-immunoreactive subpopulations of the early-generated neurons. Another possibility is that peptide immunoreactivities are correlated with the specific sets of connections, either distant or local circuit, made by subplate neurons. Regardless of how the subplate neurons exert their effect, whether it is through their interactions via the extracellular matrix, their transmitters, or their connections, it is likely that these special neurons play an instructive role in the formation of the mammalian cerebral cortex.

\section{References}

Adrian, T. E., J. M. Allen, S. R. Bloom, M. A. Ghatel, M. N. Rossor, G. W. Roberts, T. J. Crow, K. Tatemoto, and J. M. Polak (1983) Neuropeptide $Y$ distribution in human brain. Nature 306: 584-596.

Allen, Y. S., T. E. Adrian, J. M. Allen, K. Tatemoto, T. J. Crow, S. R. Bloom, and J. M. Polak (1983) Neuropeptide Y distribution in the rat brain. Science 221: 877-879.

Astrom, K.-E. (1967) On the early development of the isocortex in fetal sheep. Prog. Brain Res. 26: 1-59.

Baron, M., and A. Gallego (1971) Cajal cells of the rabbit cerebral cortex. Experientia 27: 430-432.

Bennett-Clarke, C., M. A. Romagnano, and S. A. Joseph (1980) Dis- 
tribution of somatostatin in the rat brain: Telencephalon and diencephalon. Brain Res. 188: 473-486.

Berkowitz, S. A., J. Katagiri, H. K. Binder, and R. C. Williams, Jr. (1977) Separation and characterization of microtubule proteins from calf brain. Biochemistry 16: 5610-5617.

Bernhard, C. G., I. H. Kaiser, and G. M. Kolmodin (1959) On the development of cortical activity in fetal sheep. Acta Physiol. Scand. 47: 333-349.

Bernhard, C. G., G. M. Kolmodin, and B. A. Meyerson (1967) On the prenatal development of function and structure in the somesthetic cortex of the sheep. Prog. Brain Res. 26: 60-77.

Bernhardt, R., and A. I. Matus (1982) Initial phase of dendritic outgrowth: Evidence for the involvement of high molecular weight microtubule-associated proteins (HMWP) before the appearance of tubulin. J. Cell Biol. 92: 589-593.

Bernhardt, R., and A. Matus (1984) Light and electron microscopic studies of the distribution of microtubule-associated protein 2 in rat brain: A difference between dendritic and axonal cytoskeletons. $J$. Comp. Neurol. 226: 203-221.

Bernhardt, R., G. Huber, and A. Matus (1985) Differences in the developmental patterns of three microtubule-associated proteins in the rat cerebellum. J. Neurosci. 5: 977-991.

Bittner, M., P. Kupferer, and C. F. Morris (1980) Electrophoretic transfer of proteins and nucleic acids from slab gels to diazobenzyloxymethyl cellulose or nitrocellulose sheets. Anal. Biochem. 102: 459471.

Blue, M. E., and J. G. Parnavelas (1983) The formation and maturation of synapses in the visual cortex of rat. II. Quantitative analysis. J. Neurocytol. 12: 697-712.

Boulder Committee (1970) Embryonic vertebrate central nervous system: Revised terminology. Anat. Rec. 166: 257-262.

Bradford, R., J. G. Parnavelas, and A. R. Lieberman (1977) Neurons in layer I of the developing occipital cortex of the rat. J. Comp. Neurol. 176: 121-132.

Bulloch, A. G. M. (1987) Somatostatin enhances neurite outgrowth and electrical coupling of regenerating neurons in Helisoma. Brain Res. 412: 6-17.

Caceres, A., M. R. Payne, L. I. Binder, and O. Steward (1983) Immunohistochemical localization of actin and microtubule-associated protein MAP2 in dendritic spines. Proc. Natl. Acad. Sci. USA 80 . 1738-1742.

Caceres, A., L. I. Binder, M. R. Payne, P. Bender, L. Rebhun, and O. Steward (1984) Differential subcellular localization of tubulin and the microtubule-associated protein MAP2 in brain tissue as revealed by immunocytochemistry with monoclonal hybridoma antibodies. $\mathrm{J}$. Neurosci. 4: 394-410.

Cavanagh, M. E., and J. G. Parnavelas (1988) Development of somatostatin immunoreactive neurons in the rat occipital cortex: A combined immunocytochemical-autoradiographic study. J. Comp. Neurol. 268: 1-12.

Chan-Palay, V., Y. S. Allen, W. Lang, U. Haesler, and J. M. Polak (1985) I. Cytology and distribution in normal human cerebral cortex of neurons immunoreactive with antisera against neuropeptide $Y$. J. Comp. Neurol. 238: 382-389.

Chronwall, B., and J. R. Wolff (1980) Prenatal and postnatal development of GABA-accumulating cells in the occipital neocortex of rat. J. Comp. Neurol. 190: 187-208.

Chun, J. J. M., and C. J. Shatz (1988a) A fibronectin-like molecule is present in the developing cat cerebral cortex and is correlated with subplate neurons. J. Cell Biol. 106: 857-872.

Chun, J. J. M., and C. J. Shatz (1988b) Distribution of synaptic vesicle antigens is correlated with the disappearance of a transient synaptic zone in the developing cerebral cortex. Neuron $1: 297-310$.

Chun, J. J. M., and C. J. Shatz (1989) Interstitial cells of the adult neocortical white matter are the remnant of the early-generated subplate neuron population. J. Comp. Neurol. (in press).

Chun, J. J. M., M. J. Nakamura, and C. J. Shatz (1987) Transient cells of the developing mammalian telencephalon are peptide immunoreactive neurons. Nature 325: 617-620.

Cragg, B. G. (1975) The development of synapses in the visual system of the cat. J. Comp. Neurol. 160: 147-166.

Crandall, J. E., and V. S. Caviness, Jr. (1984) Thalamocortical connections in newborn mice. J. Comp. Neurol. 228: 542-556.

Crandall, J. E., M. Jacobson, and K. S. Kosik (1986) Ontogenesis of microtubule-associated protein 2 (MAP2) in embryonic mouse cortex. Dev. Brain Res. 28: 127-133.
De Camilli, P., P. E. Miller, F. Navone, W. E. Theurkauf, and R. B. Vallee (1984) Distribution of microtubule-associated protein 2 in the nervous system of the rat studied by immunofluorescence. Neuroscience 11: 819-846.

Derer, P. (1974) Histogenese du neocortex du rat albinos durant la periode foetale et neonatale. J. Hirnforsch. 15:49-74.

Edmunds, S. M., and J. G. Parnavelas (1982) Retzius-Cajal cells: An ultrastructural study in the developing visual cortex of the rat. J. Neurocytol. 11: 427-446.

Finley, J. C. W., J. L. Maderdrut, L. J. Roger, and P. Petrusz (1981) The immunocytochemical localization of somatostatin-containing neurons in the rat central nervous system. Neuroscience $6: 2173-$ 2192.

Foster, G. A., and M. Schultzberg (1984) Immunohistochemical analysis of the ontogeny of neuropeptide $Y$ immunoreactive neurons in the foetal rat brain. Int. J. Dev. Neurosci. 2: 387-407.

Godina, G. (1951) Istogenesi e differenziazione die neuroni e degli elementi gliale della corteccia cerebrale. Z. Zellforsch. 36: 401-435.

Haydon, P. G., D. P. McCobb, and S. B. Kater (1987) The regulation of neurite outgrowth, growth cone motility and electrical synaptogenesis by serotonin. J. Neurobiol. 18: 197-215.

Hendrickson, A., S. P. Hunt, and J.-Y. Wu (1981) Immunocytochemical localisation of glutamic acid decarboxylase in monkey striate cortex. Nature 292: 605-607.

Hendry, S. H. C., E. G. Jones, and M. C. Beinfeld (1983) Cholecystokinin-immunoreactive neurons in rat and monkey cerebral cortex make symmetric synapses and have intimate associations with blood vessels. Proc. Natl. Acad. Sci. USA 80: 2400-2404.

Hendry, S. H. C., E. G. Jones, and P. C. Emson (1984a) Morphology, distribution, and synaptic relations of somatostatin- and neuropeptide $\mathrm{Y}$-immunoreactive neurons in rat and monkey neocortex. J. Neurosci. 4: 2497-2517.

Hendry, S. H. C., E. G. Jones, J. DeFelipe, D. Schmechel, C. Brandon, and P. C. Emson (1984b) Neuropeptide-containing neurons of the cercbral cortcx arc also GABAcrgic. Proc. Natl. Acad. Sci. USA 81: 6526-6530.

Hickey, T. L., D. R. Whikehart, C. A. Jackson, P. F. Hitchcock, and J. D. Peduzzi (1983) Tritiated thymidine experiments in the cat: A description of techniques and experiments to define the time-course of radioactive thymidine availability. J. Neurosci. Methods 8: 139_ 147.

Huttenlocher, P. R. (1967) Development of cortical neuronal activity in the neonatal cat. Exp. Neurol. 17: 247-262.

Innis, R. B., F. M. A. Correa, G. R. Uhl, B. Schneider, and S. H. Snyder (1979) Cholecystokinin octapeptide-like immunoreactivity: Histochemical localization in rat brain. Proc. Natl. Acad. Sci. USA 76 : $521-525$.

Innocenti, G. M. (1981) Growth and reshaping of axons in the establishment of visual callosal conncctions. Science 212:824-827.

Kato, N., S. Kawaguchi, and H. Miyata (1984) Geniculocortical projection to layer 1 of area 17 in kittens: Orthograde and retrograde HRP studies. J. Comp. Neurol. 225: 441-447.

Kolliker, A. (1896) Handbuch der Gewebelehre des Menschen. Nervous System des Menschen und der Thiere. Engelman, Leipzig.

Konig, N., G. Roch, and R. Marty (1975) The onset of synaptogenesis in the rat temporal cortex. Anat. Embryol. 148: 73-87.

Konig, N., J.-P. Hornung, and H. Van Der Loos (1981) Identification of Cajal-Retzius cells in immature rodent cerebral cortex: A combined Golgi-EM study. Neurosci. Lett. 27: 225-229.

Kostovic, I., and M. E. Molliver (1974) A new interpretation of the laminar development of cerebral cortex: Synaptogenesis in different layers of neopallium in the human fetus. Anat. Rec. 178: 395 (Abstr.)

Kostovic, I., and P. Rakic (1980) Cytology and time of origin of interstitial neurons in the white matter in infant and adult human monkey telencephalon. J. Neurocytol. 9: 219-242.

Kostovic, I., and P. Rakic (1984) Development of prestriate visual projections in the monkey and human fetal cerebrum revealed by transient cholinesterase staining. J. Neurosci. 4: 25-42.

Kristt, D. A., and M. E. Molliver (1976) Synapses in newborn rat cerebral cortex: A quantitative ultrastructural study. Brain Res. 108. 180-186.

Laemle, L. K., and S. C. Feldman (1985) Somatostatin (SRIF)-like immunoreactivity in subcortical and cortical visual centers of the rat. J. Comp. Neurol. 233: 452-462.

Laemmli, U.K. (1970) Cleavage of structural proteins during assembly of the head of bacteriophage T4. Nature (Lond.) 227: 680-685. 
Lauder, J. M., V. K. M. Han, P. Henderson, T. Verdoorn, and A. C. Towle (1986) Prenatal ontogeny of the gabergic system in the rat brain: An immunocytochemical study. Neuroscience 19: 465-493.

LeVay, S., M. P. Stryker, and C. J. Shatz (1978) Ocular dominance columns and their development in layer IV of the cat's visual cortex: A quantitative study. J. Comp. Neurol. 179: 223-244.

Lorente de No, R. (1933) Studies on the structure of the cerebral cortcx. J. Psychol. Neurol. 45: 381-438.

Lund, J. S., R. G. Boothe, and R. D. Lund (1977) Development of neurons in the visual cortex (area 17) of the monkey (Macaca nemestrina): A Golgi study from fetal day 127 to postnatal maturity. J. Comp. Neurol. 176: 149-188.

Lund, R. D., and M. J. Mustari (1977) Development of the geniculocortical pathway in rats. J. Comp. Neurol. 173: 289-306.

Luskin, M. B., and C. J. Shatz (1985a) Studies of the earliest generated cells of the cat's visual cortex: Cogeneration of subplate and marginal zones. J. Neurosci. 5: 1062-1075.

Luskin, M. B., and C. J. Shatz (1985b) Neurogenesis of the cat's primary visual cortex. J. Comp. Neurol. 242: 611-631.

Marin-Padilla, M. (1971) Early prenatal ontogenesis of the cerebral cortex (neocortex) of the cat (Felis domestica). A Golgi study. I. The primordial neocortical organization. Z. Anat. Entwickl.-Gesch. 134: 117-145.

Marin-Padilla, M. (1972) Prenatal ontogenetic history of the principal neurons of the neocortex of the cat (Felis domestica). A Golgi study II. Developmental differences and their significance. Z. Anat. Entwickl.-Gesch. 136: 125-142.

Marin-Padilla, M. (1978) Dual origin of the mammalian neocortex and evolution of the cortical plate. Anat. Embryol. 152: 109-126.

Marin-Padilla, M., and T. M. Marin-Padilla (1982) Origin, prenatal development and structural organization of layer I of the human cerebral (motor) cortex. Anat. Embryol. 164: 161-206.

Matus, A., R. Bernhardt, and H.-J. Jones (1981) High molecular weight microtubule-associated proteins are preferentially associated with dendritic microtubules in brain. Proc. Natl. Acad. Sci. USA 787: 3010-3014.

McConnell, S. K. (1988) Development and decision-making in the mammalian cerebral cortex. Brain Res. Rev. 13: 1-23.

McConnell, S. K., and C. J. Shatz (1988) Prenatal development of axonal projections from the cat's visual cortex. Soc. Neurosci. Abstr. 14: 743 .

Meyer, G., and P. Wahle (1988) The early postnatal development of CCK-ir structures in the visual cortex of the cat. J. Comp. Neurol. 276: 360-386.

Meyerson, B. A., and H. E. Persson (1969) Evoked unitary and gross electric activity in the cerebral cortex in early prenatal ontogeny. Nature 221: 1248-1249.

Miller, P., U. Walter, W. Theurkauf, R. B. Vallee, and P. De Camilli (1982) Frozen tissue sections as an experimental system to reveal specific binding sites for the regulatory subunit of type II cAMPdependent protein kinase in neurons. Proc. Natl. Acad. Sci. USA 79: 5562-5566.

Molliver, M. E. (1967) An ontogenetic study of evoked somesthetic cortical responses in the sheep. Prog. Brain Res. 26: 78-91.

Molliver, M. E., and H. Van der Loos (1970) The ontogenesis of cortical circuitry: The spatial distribution of synapses in somesthetic cortex of newborn dog. Ergebn. Anatom. Entwicklungsgeschichte 42: $7-35$.

Molliver, M. E., I. Kostovic, and H. Van der Loos (1973) The development of synapses in cerebral cortex of the human fetus. Brain Res. 50: 403-407.

Naus, C. C., F. D. Miller, J. H. Morrison, and F. E. Bloom (1988) Immunohistochemical and in situ hybridization analysis of the development of the rat somatostatin-containing neocortical neuronal system. J. Comp. Neurol. 269: 448-463.

Parnavelas, J. G., and A. Chatzissavidou (1981) The development of the thalamic projections to layer I of the visual cortex of the rat. Anat. Embryol. 163: 71-75.

Parnavelas, J. G., and S. M. Edmunds (1983) Further evidence that Retzius-Cajal cells transform to nonpyramidal neurons in the developing rat visual cortex. J. Neurocytol. 132: 863-871.

Purpura, D. P. (1961a) Morphophysiological basis of elementary evoked response patterns in the neocortex of the new born cat. Ann. NY Acad. Sci. 92: 840-859.
Purpura, D. P. (1961b) Ontogenetic analysis of some evoked synaptic activities in superficial neocortical neuropil. In Nervous Inhibition, E. Florey, ed., pp. 424-446, Pergamon, New York.

Purpura, D. P., R. J. Shofer, and T. Scarff (1965) Properties of synaptic activities and spike potentials of neurons in immature neocortex. $J$. Neurophysiol. 28: 925-942.

Racdler, A., and J. Sicvers (1976) Light and electron microscopical studies on specific cells of the marginal zone in the developing rat cerebral cortex. Anat. Embryol. 149: 173-181.

Raedler, E., and A. Raedler (1978) Autoradiographic study of early neurogenesis in rat neocortex. Anat. Embryol. 154: 267-284.

Raedler, E., A. Raedler, and S. Feldhaus (1980) Dynamical aspects of neocortical histogenesis in the rat. Anat. Embryol. 158: 253-269.

Rakic, P. (1972) Mode of cell migration to the superficial layers of fetal monkey neocortex. J. Comp. Neur. 145: 61-84.

Rakic, P. (1977) Prenatal development of the visual system in rhesus monkey. Phil. Trans. R. Soc. Lond. B. 278: 245-260.

Ramón y Cajal, S. (1891) Sur la structure de l'ecorce cerebrale de quelques mammiferes. La Cellule 7: 125-176.

Ramón y Cajal, S. (1911) Histologie du Systeme Nerveux de l'Homme et des Vertebres. Vol. II, pp. 519-598, Maloine, Paris (reprinted, Madrid, 1952).

Retzius, G. (1891) Ueber den Bau der Olerflachenschicht der Grosshirnrinde beim Menschen und beiden Saugethieren. Verh. Biol. Ver. (Stockh.) 3: 90-103.

Ribak, C. E. (1978) Aspinous and sparsely-spinous stellate neurons in the visual cortex of rats contain glutamic acid decarboxylase. J. Neurocytol. 7: 461-478.

Rickmann, M., and J. R. Wolff (1981) Differentiation of "preplate" neurons in the pallium of the rat. Bibl. Anat. 19: 142-146.

Rickmann, M., B. M. Chronwall, and J. R. Wolff (1977) On the development of non-pyramidal neurons and axons outside the cortical plate: The early marginal zone as a pallial anlage. Anat. Embryol. 151: 285-307.

Sas, E., and F. Sanides (1970) A comparative study of the Cajal foetal cells. Z. Mikro-Anat. Forsch. 82: 385-396.

Schmechel, D. E., B. G. Vickrey, D. Fitzpatrick, and R. P. Elde (1984) Gabergic neurons of mammalian cerebral cortex: Widespread subclass defined by somatostatin content. Neurosci. Lett. 47:227-232.

Shatz, C. J., and M. B. Luskin (1986) The relationship between the geniculocortical afferents and their cortical target cells during development of the cat's primary visual cortex. J. Neurosci. 6: 3655-3668.

Shatz, C. J., J. J. M. Chun, and M. B. Luskin (1988) The role of the subplate in the development of the mammalian telencephalon. In The Cerebral Cortex, Vol. 7, A. Peters and E. G. Jones, eds., pp. 35-58, Plenum, New York

Somogyi, P., A. J. Hodgson, A. D. Smith, M. G. Nunzi, A. Gorio, and J.-Y. Wu (1984) Different populations of gabergic neurons in the visual cortex and hippocampus of cat contain somatostatin- or cholecystokinin-immunoreactive material. J. Neurosci. 4: 2590-2603.

Sorensen, K. V. (1982) Somatostatin: Localization and distribution in the cortex and subcortical white matter. Neuroscience 7: 12271232.

Stensaas, L. J. (1967a) The development of the hippocampal and dorsolateral pallial regions of the cerebral hemisphere in fetal rabbits. I. Fifteen millimeter stage, spongioblast morphology. J. Comp. Neurol. 129: $59-70$.

Stensaas, L. J. (1967b) The development of the hippocampal and dorsolateral pallial regions of the cerebral hemisphere in fetal rabbits. II. Twenty millimeter stage, neuroblast morphology. J. Comp. Neurol 129: 71-84.

Stensaas, L. J. (1967c) The development of the hippocampal and dorsolatcral pallial regions of the cerebral hemisphere in fetal rabbits. IV. Forty-one millimeter stage, intermediate lamina. J. Comp. Neurol. 131: 409-422.

Stensaas, L. J. (1967d) The development of hippocampal and dorsolateral pallial region of the cerebral hemisphere in fetal rabbits. V. Sixty millimeter stage, glial cell morphology. J. Comp. Neurol. 131: $423-436$

Stewart, G. R., and A. L. Pearlman (1987) Fibronectin-like immunoreactivity in the developing cerebral cortex. J. Neurosci. 7:33253333.

Sugita, N. (1917) Comparative studies on the growth of the cerebral cortex. J. Comp. Neurol. 28: 511-591. 
Towbin, H., T. Staehelin, and J. Gordon (1979) Electrophoretic transfer of proteins from polyacrylamide gels to nitrocellulose sheets: Procedure and some applications. Proc. Natl. Acad. Sci. USA 76:43504354.

Vallee, R. B. (1982) A taxol-dependent procedure for the isolation of microtubule and microtubule-associated proteins (MAPs). J. Cell Biol. 92: $435-442$.

Valverde, F., and M. V. Facal-Valverde (1988) Postnatal development of interstitial (subplate) cells in the white matter of the temporal cortex of kittens. A correlated Golgi and electron microscopic study. J. Comp. Neurol. 269: 168-192.

Wahle, P., and G. Meyer (1987) Morphology and quantitative changes of transient NPY-ir neuronal populations during early postnatal development of the cat visual cortex. J. Comp. Neurol. 261: 165-192.

Wahle, P., G. Meyer, J.-Y. Wu, and K. Albus (1987) Morphology and axon terminal pattern of glutamate decarboxylase-immunoreactive cell types in the white matter of the cat occipital cortex during early postnatal development. Dev. Brain Res. 36: 53-61.

Wise, S. P., and E. G. Jones (1976) The organization and postnatal development of the commissural projection of the rat somatic sensory cortex. J. Comp. Neurol. 168: 313-344.

Wise, S. P., and E. G. Jones (1978) Developmental studies of thalamocortical and commissural connections in the rat somatic sensory cortex. J. Comp. Neurol. 175: 187-208.

Wise, S. P., S. H. C. Hendry, and E. G. Jones (1977) Prenatal development of sensorimotor cortical projections in cats. Brain Res. 138: $538-544$

Wolff, J. R. (1976) Quantitative analysis of topography and development of synapses in visual cortex. Exp. Brain Res. (Suppl.) 1:259263.

Wolff, J. R., H. Bottcher, T. Zetzshe, W. H. Oertel, and B. M. Chronwall (1984) Development of gabergic neurons in rat visual cortex as identified by glutamate decarboxylase-like immunoreactvity. Neurosci. Lett. 47: 207-212.

Woodhams, P. L., Y. S. Allen, J. McGovern, J. M. Allen, S. R. Bloom, R. Balazs, and J. M. Polak (1985) Immunohistochemical analysis of the early ontogeny of the neuropeptide $Y$ systcm in rat brain. Neuroscience 15: 173-202. 